\title{
Article \\ Contamination Levels and the Ecological and Human Health Risks of Potentially Toxic Elements (PTEs) in Soil of Baoshan Area, Southwest China
}

\author{
Li Zhang ${ }^{1,2,3, * \mathbb{D}}$, Zheng Yang ${ }^{1,2,3}$, Min Peng ${ }^{1,2,3}$ and Xiaomeng Cheng ${ }^{1}$ \\ 1 Institute of Geophysical and Geochemical Exploration, Chinese Academy of Geological Sciences, \\ Langfang 065000, China; yzheng@mail.cgs.gov.cn (Z.Y.); pmin@mail.cgs.gov.cn (M.P.); \\ cxiaomeng@mail.cgs.gov.cn (X.C.) \\ 2 Key Laboratory of Geochemical Cycling of Carbon and Mercury in the Earth's Critical Zone, \\ Chinese Academy of Geological Sciences, Langfang 065000, China \\ 3 Research Center of Geochemical Survey and Assessment on Land Quality, China Geological Survey, \\ Langfang 065000, China \\ * Correspondence: zhangli01@mail.cgs.gov.cn
}

Citation: Zhang, L.; Yang, Z.; Peng, M.; Cheng, X. Contamination Levels and the Ecological and Human Health Risks of Potentially Toxic Elements (PTEs) in Soil of Baoshan Area, Southwest China. Appl. Sci. 2022, 12, 1693. https://doi.org/ 10.3390/app12031693

Academic Editor: Nathan J Moore

Received: 2 January 2022

Accepted: 26 January 2022

Published: 7 February 2022

Publisher's Note: MDPI stays neutral with regard to jurisdictional claims in published maps and institutional affiliations.

Copyright: (C) 2022 by the authors. Licensee MDPI, Basel, Switzerland. This article is an open access article distributed under the terms and conditions of the Creative Commons Attribution (CC BY) license (https:// creativecommons.org/licenses/by/ $4.0 /)$.

\begin{abstract}
The primary goals of this study were to reveal the environmental status of potentially toxic elements (PTEs) and their ecological risks, as well as their associated health risks in the Baoshan area, southwest China, which has been surveyed with the scale of 1:250,000 geochemical mapping. Based on a comparison of the PTE concentrations with the soil environmental quality of China and the enrichment factor $(\mathrm{EF})$, geo-accumulation index $\left(\mathrm{I}_{\text {geo }}\right)$, contamination factor $\left(\mathrm{C}_{\mathrm{f}}\right)$, and potential ecological risk indexes ( $E_{r}^{i}$ and PERI), as well as the potential non-carcinogenic hazard indices (HI and $\mathrm{CHI}$ ) and carcinogenic risks indices (TCR and CTCR), the following conclusions were drawn: The PTE concentrations in the surface soil samples that were collected from the investigated area (1.65\% sites) exceeded the risk intervention values (RIV) for soil contamination of agricultural land of China. Cadmium $(\mathrm{Cd})$ and mercury $(\mathrm{Hg})$ posed higher ecological risks than other PTEs (arsenic (As), chromium $(\mathrm{Cr})$, lead $(\mathrm{Pb})$, copper $(\mathrm{Cu})$, nickel $(\mathrm{Ni})$, and zinc $(\mathrm{Zn}))$, which was highlighted by their toxic response factor. Arsenic was the main PTE with a non-carcinogenic risk $(19.57 \%$ sites for children and $0.25 \%$ sites for adults) and the only PTE that carries a carcinogenic risk $(2.67 \%$ sites for Children and $0.76 \%$ sites for adults) to humans in the research area. Children are more vulnerable to health risks when compared to adults because of their behavioral and physiological traits. Geological genesis was responsible for the high concentrations, ecological risk, and health risk distribution patterns of the examined PTEs. Even though the present research highlights several important aspects related to PTE pollution in the research area, further investigations are needed, especially in mining areas.
\end{abstract}

Keywords: soil PTEs; ecological risks; human health risks; the Baoshan area; southwest China

\section{Introduction}

Soil is the foundation of food production systems and is a critical component for national food security. Soil quality has become a key concern internationally due to competing demands between people, resources, and the environment [1-7]. Specifically, the potentially toxic elements (PTEs) such as arsenic (As), cadmium (Cd), chromium $(\mathrm{Cr})$, mercury $(\mathrm{Hg})$, lead $(\mathrm{Pb})$, copper $(\mathrm{Cu})$, nickel $(\mathrm{Ni})$, and zinc $(\mathrm{Zn})$ in soil have received significant attention in the past few decades due to their widespread distribution and severe toxicity to plants, animals, and humans. Oral ingestion (such as unintentional/intentional hand-oral ingestion), respiratory inhalation (as dust via respiratory inhalation), and dermal contact are the main routes through which PTEs from soil can be transferred into the human body [8-13]. Excessive intake or long-term exposure to PTEs may cause adverse effects to 
human beings, example of which being that As is a recognized human carcinogen that has been linked to an increased risk of adverse health effects in children, including cognitive impairment [14-18]. Excessive Cd content increases the risks of postmenopausal breast cancer and upper gastrointestinal cancer, as well as kidney and bone damage [19]. Children experience higher non-carcinogenic health risks caused by $\mathrm{Pb}$ through ingestion when compared to adults [20]. Long-term exposure to low concentrations of $\mathrm{Pb}$ may damage a child's brain during development and may result in neurological issues [21]. Hg may be found in a variety of forms, including in their metallic, elemental, inorganic, and organic forms in the environment [22]. Exposure to high levels of methyl mercury during the second trimester of pregnancy might damage the fetus' neurological system and may cause issues with language, attention, and memory [23-25]. Despite the fact that $\mathrm{Cu}, \mathrm{Cr}$, $\mathrm{Zn}$, and $\mathrm{Ni}$ are essential trace elements for human health, chronic and excessive intake may lead to damaging effects on human beings [26]. When $\mathrm{Cr}, \mathrm{Cu}, \mathrm{Zn}$, and $\mathrm{Ni}$ levels reach their acceptable threshold values, they can induce non-carcinogenic risks, such as neurologic involvement, headaches, liver and renal illness, and skin and respiratory system lesions [27-30]. The side effects of excessive Ni consumption and exposure include contact dermatitis, cardiovascular illness, asthma, lung fibrosis, and respiratory tract cancer [31].

Soil plays a crucial role in the biogeochemical transformation of the top layer of the lithosphere [32]. PTEs enter the soil system in a variety of ways, both naturally and anthropogenically. Naturally, PTE soil contamination occurs as a result of the weathering process of parent materials that contain significant levels of PTEs [2,32-37]. Anthropogenically, the soil has been contaminated by fast industrial expansion and subsequent effluent discharge or exhaust emissions, agricultural fertilizers and pesticides, mining operations, population explosions, and subsequent urban dwelling pollution [6,38-45]. Anthropogenic activities are generally regarded as being the primary source of PTEs in the soil in highly developed, urbanized and industrial urban areas [46-49], mining areas [5,50-52], or agricultural sectors $[41,53]$. However, a large body of research on this subject supports the importance of the geological background in contributing to higher PTE contents in soil [2,33-37,54,55].

The PTE levels in soil are frequently elevated due to mineral resources (such as $\mathrm{Cu}$, $\mathrm{Pb}, \mathrm{Zn}$, and $\mathrm{Hg}$ ), as well as carbonate and basalt parent materials [56-63]. This phenomenon can be observed in the soils of the Baoshan area in Yunnan province, southwest China, where mineral resources and carbonate and basalt parent materials are widely distributed $[54,55,64]$. Previous study has shown the concentrations and the distribution of selected elements (including PTEs) in the soil and river sediments of the Baoshan area, based on the data from the 1: 250,000 scale National Geochemistry Survey of Land Quality project (NGSLQ) and archived river sediment samples collected and analyzed in the Regional Geochemistry-National Reconnaissance (RGNR) program based in this area $\left(6220 \mathrm{~km}^{2}\right)$ [54]. The distribution of PTEs in surface and deep soil are mainly influenced by natural factors (basic igneous rocks, carbonate rocks, and mineralization), while the surface soil near mining areas is aggravated by mining related activities in the Baoshan area $[54,55]$. The environmental ecological risks of the soil and the human health risks connected with PTEs, as well as these risks' spatial distribution, have not been designated in the Baoshan area. It is critical to analyze environmental ecological and health risks and outline the risk distribution, for local and national authorities and environmental protection agencies to make environmental management decisions. The evaluated results may provide a useful reference for areas with a similar geological background or mineral resource conditions.

The aims of this research were to: (1) evaluate PTE (As, Cd, Cr, $\mathrm{Hg}, \mathrm{Pb}, \mathrm{Cu}, \mathrm{Ni}$, and $\mathrm{Zn}$ ) pollution levels in the soil; (2) assess the ecological risk of PTEs in soil and their health risks to humans; (3) map the risk level distribution to allow direct appraisal; and (4) make recommendations to authorities and environmental protection agencies. 


\section{Methodology}

\subsection{Study Area}

The Baoshan area is located in Yunnan province, Southwest China (Figure 1a), has a low latitude and moderate elevation, and is tempered by a mild subtropical climate with short, mild, and dry winters and warm, wet summers. Variations in the average temperature are closely connected to altitude, while the western and southern parts of the study area experience the highest amount of rainfall $[54,55,64]$. The main land-use types in the study area are forested land, dry cultivated land, paddy land, grassland, and garden plots, with few water areas or other land types (residential quarters, industrial and mining land, and unused land) (Figure 1c) [54,55].
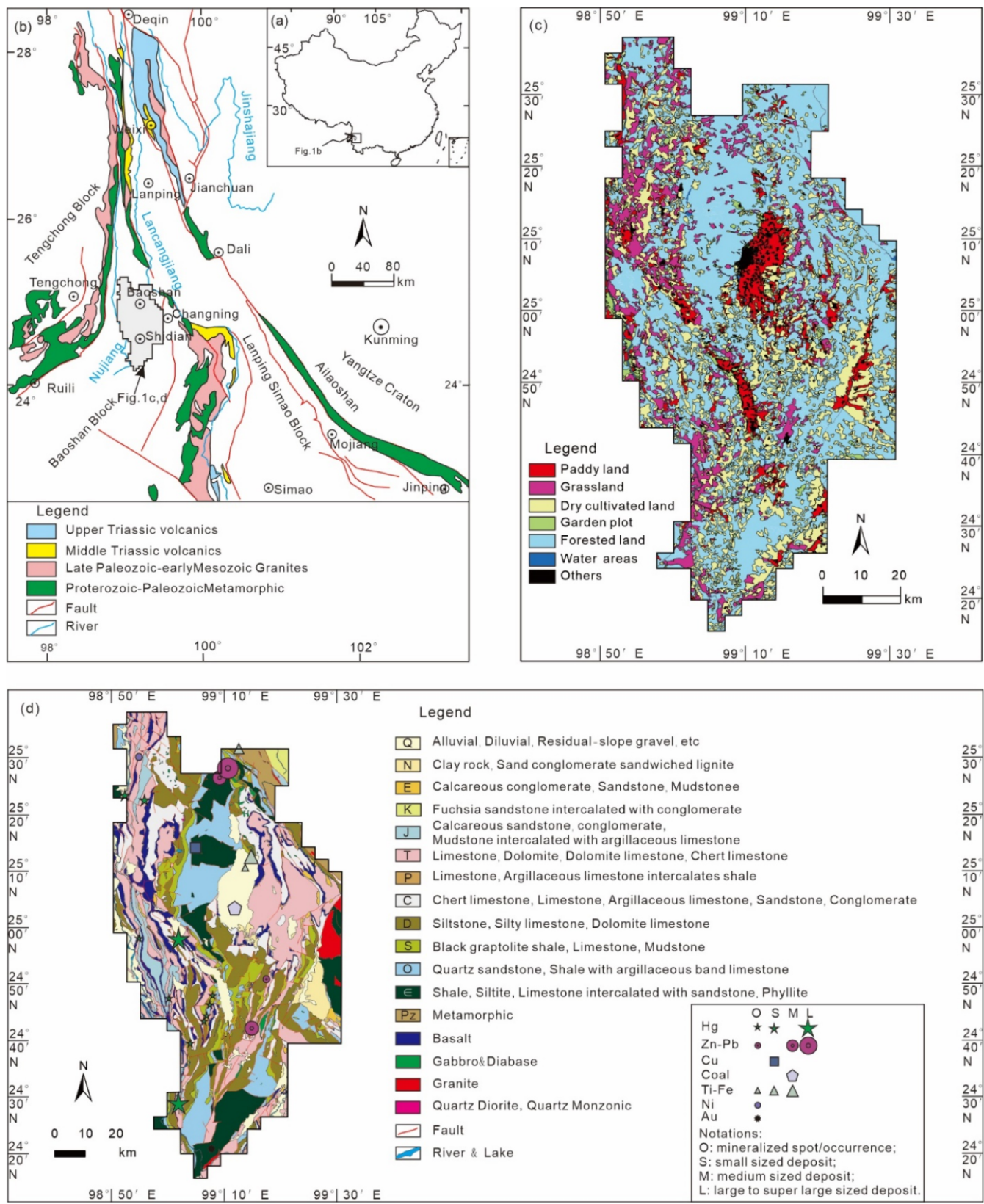

Figure 1. General situation of the study area, reproduced from [54,55], with permission from Elsevier, 2022; (a) location of the study area in China; (b) simplified tectonic map of Yunnan Sanjiang area; (c) simplified land-use map of the study area; (d) simplified geological and mineral deposits map of the study area. 
Geologically, Baoshan is located in the Sanjiang area of Yunnan province, which consists of the Tengchong, Baoshan, and Lanping-Simao blocks (Figure 1b) [65-67]. The rock types of the Baoshan Block are mainly Paleozoic to Mesozoic sedimentary rocks and Early Paleozoic and Late Mesozoic-Early Cenozoic magmatic rocks [65,68]. Precambrian to Quaternary strata and sporadic granite and diabase intrusions are found in the study area (Figure 1d). Basalt occurs in the Carboniferous and Jurassic rock sequences that are mainly distributed in the western and northeastern parts of the study area (Figure 1d), whereas mineral deposits, which often lead to PTE pollution in soil, are widely distributed across the study area, which include large $\mathrm{Cu}-\mathrm{Pb}-\mathrm{Zn}$ and $\mathrm{Hg}$ workings (Figure 1d) [54,55].

\subsection{Samples Collection, Preparation, Chemical Analysis and Quality Control}

Sample collection, preparation, chemical analysis, and quality control in the study area have been described in detail in a prior study [54].

In this study, a total of 1574 surface soil $(0-20 \mathrm{~cm})$ and 425 deep soil $(150-180 \mathrm{~cm}$ or soil from the $C$ horizon if the soil depth is less than $150 \mathrm{~cm}$ ) composed datasets were used [54], which were collected in 2016 as part of the NGSLQ project in the Baoshan area $\left(6220 \mathrm{~km}^{2}\right)$ using a systematic regular grid-sampling method [69]. In the research area, surface soils were collected at a density of 1 sample $/ \mathrm{km}^{2}$ and deep soils were collected at a density of 1 sample $/ 4 \mathrm{~km}^{2}$. To assess sampling variation, about $1 \%$ of the sample sites were re-sampled. The samples were disaggregated with a wooden hammer during air drying and were sieved using a 20 mesh screen $(0.84 \mathrm{~mm})$ after drying. They were further processed with a -200 mesh screen $(0.074 \mathrm{~mm})$ for analysis. Surface soil samples from $4 \mathrm{~km}^{2}$ and deep soil samples from $16 \mathrm{~km}^{2}$ were composited for analysis to lower the analytical cost [4].

The total content of 54 elements or indictors, including PETs (such as As, Cd, Cr, $\mathrm{Hg}$, $\mathrm{Pb}, \mathrm{Cu}, \mathrm{Ni}$, and $\mathrm{Zn}$ ), and the $\mathrm{pH}$ of the composited soil samples were analyzed at the Central Analytical Laboratory of the Institute of Geophysical and Geochemical Exploration (IGGE). Samples were analyzed as dry weight. As was analyzed by means of Hydride Generation-Atomic Fluorescence Spectrometry (HG- AFS) after digestion by aqua regia; $\mathrm{Cd}, \mathrm{Cu}, \mathrm{Ni}, \mathrm{Pb}$, and $\mathrm{Zn}$ were analyzed by Inductively Coupled Plasma-Mass Spectrometry (ICP-MS) after digestion by hydrofluoric acid ( $\mathrm{HF})$, nitric acid $\left(\mathrm{HNO}_{3}\right)$, perchloric acid $\left(\mathrm{HClO}_{4}\right)$, and aqua regia; $\mathrm{Cr}$ was analyzed by X-Ray Fluorescence Spectrometry (XRF) after powder pellet formation; $\mathrm{Hg}$ was analyzed by Cold Vapor-Atomic Fluorescence Spectrometry (CV-AFS) after digestion by aqua regia; $\mathrm{pH}$ was analyzed by Ion-Selective Electrodes (ISE) dissolved in $\mathrm{CO}_{2}$-distilled water. During the routine analysis, internal and external controls were introduced to ensure accuracy and precision. Briefly, Certified Reference Materials (CRMs) and Blind Reference Materials (BRMs) were analyzed with the samples simultaneously. Approximately $5 \%$ of the samples were chosen at random and were re-analyzed. Within each batch of 50 samples, 4 BRMs were placed in a cipher and examined at the same time. The analytical methods, detection limits and detailed analytical procedures met the analytical requirements set in the NGSLQ project for all elements in all samples [69].

\subsection{Pollution Estimation and Risk Assessment}

Certain indicators have been used in environmental studies on PTEs in soil to assess the severity of pollution, potential ecological risk, and potential health risks to human beings that they cause [70-72].

\subsubsection{Pollution Evaluation Indicators}

To assess soil contamination levels, important indices such as the enrichment factor (EF), geo-accumulation index $\left(\mathrm{I}_{\text {geo }}\right)$, and contamination factor $\left(\mathrm{C}_{\mathrm{f}}\right)$ are widely used $[5,52,73-75]$. The indicators are calculated using the Equations below for completeness:

$$
\mathrm{EF}=\frac{\left(C_{i} / C_{r}\right)_{\text {soil }}}{\left(C_{i} / C_{r}\right)_{\text {background }}}
$$


The EF is a valuable geochemical instrument for assessing the degree of PTE contamination in soil, where "soil" denotes surface soil, "background" denotes background, " $C_{i}$ " is the concentration of the selected PTE, and " $C_{r}$ " denotes the concentration of the reference element.

Because of the non-mobile character during weathering, $\mathrm{Al}, \mathrm{Ti}, \mathrm{V}, \mathrm{Zr}$, and Sc are often chosen as reference elements [57,76-78]. EF $<2$ indicates depletion to a minimal contamination; $\mathrm{EF}=2<\mathrm{EF}<5$, moderate contamination; $\mathrm{EF}=5<\mathrm{EF}<20$, significant contamination; $\mathrm{EF}=20<\mathrm{EF}<40$, very strong contamination; $\mathrm{EF}>40$, extreme contamination, according to the classification [70].

$$
\mathrm{I}_{\text {geo }}=\log 2\left[\frac{C_{i}}{1.5 C_{b}}\right]
$$

where " $C_{i}$ " is the concentration of a selected PTE in surface soil, and " $C_{b}$ " is the background level of that PTE [71]. I $\mathrm{I}_{\text {geo }} \leq 0$ : uncontaminated; $0<\mathrm{I}_{\text {geo }} \leq 1$ : slightly contaminated; $1<\mathrm{I}_{\text {geo }} \leq 2$ : moderately contaminated; $2<\mathrm{I}_{\text {geo }} \leq 3$ : moderately to highly contaminated; $3<\mathrm{I}_{\text {geo }} \leq 4$ : highly contaminated; $4<\mathrm{I}_{\text {geo }} \leq 5$ : highly to extremely contaminated; $\mathrm{I}_{\text {geo }}>5$ : extremely contaminated, according to the classification [71].

$$
\mathrm{C}_{\mathrm{f}}=\frac{C_{i}}{C_{b}}
$$

where " $C_{i}$ " denotes PTE concentration in surface soil, " $C_{b}$ " denotes the background PTE concentration. This indictor represents the impact or contribution of an individual PTE on soil contamination. The $\mathrm{C}_{\mathrm{f}}$ can be divided into four categories: $\mathrm{C}_{\mathrm{f}}<1$ : low contamination; $1<\mathrm{C}_{\mathrm{f}}<3$ : reasonable contamination; $3<\mathrm{C}_{\mathrm{f}}>6$ : considerable contamination; $\mathrm{C}_{\mathrm{f}}>6$ : high or very high contamination [72]. The background level was measured using the deep soil from the 1:250,000 scale land quality geochemistry data from the Baoshan area, since it is considerably less likely to be impacted by human activity [54,79]. The median values of the PTEs in the deep soil of the Baoshan area were used as the background values to calculate Equations (1)-(3).

\subsubsection{Ecological Risk Assessment}

The potential ecological risk $\left(E_{r}^{i}\right)$ of a given PTE and the potential ecological index (PERI), which indicates the sum of potential ecological risks, are commonly employed at the regional and/or global levels to assess the potential impact of the pollutants in soil on ecosystems [72].

$$
\begin{gathered}
E_{r}^{i}=T_{r}^{i} \times C_{\mathrm{f}} \\
\text { PERI }=\sum E_{r}^{i}
\end{gathered}
$$

where " $\mathrm{C}_{\mathrm{f}}$ " is the contamination factor calculated in Equation (3), " $T_{r}^{i \text { " }}$ is the toxic response factor of a given PTE calculated using $\mathrm{Hg}=40, \mathrm{Cd}=30, \mathrm{As}=10, \mathrm{~Pb}=5, \mathrm{Cu}=5, \mathrm{Ni}=5$, $\mathrm{Cr}=2$, and $\mathrm{Zn}=1$ [72] $E_{r}^{i}$ can be classified as $E_{r}^{i}<40$ : low potential ecological risk; $40 \leq E_{r}^{i}<80$ : moderate potential ecological risk; $80 \leq E_{r}^{i}<160$ : considerable potential ecological risk; $160 \leq E_{r}^{i}<320$ : high potential ecological risk; $E_{r}^{i} \geq 320$ : very high potential ecological risk [72]. PERI can be classified as PERI < 150: low potential ecological risk; $150 \leq$ PERI < 300: moderate potential ecological risk; $300 \leq$ PERI < 600: considerable potential ecological risk; $600 \leq$ PERI $<1200$ : high potential ecological risk; PERI $\geq 1200$ : very high potential ecological risk [72].

\subsubsection{Human Health Risk Assessment}

A variety of preventative methods have been developed to evaluate the health risks caused by contaminants in order to maintain public health. The potential human health risk models raised by the US EPA, which include carcinogenic and non-carcinogenic risks [80], have proven successful and have been used globally [5,13,52,74,81]. 
The direct exposure of children and adults to PETs through soils was taken into account when calculating the human health risk.

The Equations. below were used to calculate chronic daily intake (CDI) of PTEs exposure ingestion $\left(\mathrm{CDI}_{\text {ingestion }}\right)$, inhalation $\left(\mathrm{CDI}_{\text {inhalation }}\right)$, and dermal contact $\left(\mathrm{CDI}_{\text {dermal }}\right)$ [74] The exposure factors for health risk assessment mentioned in the following Equations. are listed in Table 1.

$$
\begin{gathered}
\mathrm{CDI}_{\text {ingestion }}=\frac{\mathrm{C} \times \mathrm{IngR} \times \mathrm{EF} \times \mathrm{ED} \times \mathrm{CF}}{\mathrm{BW} \times \mathrm{AT}} \\
\mathrm{CDI}_{\text {inhalation }}=\frac{\mathrm{C} \times \mathrm{InhR} \times \mathrm{EF} \times \mathrm{ED}}{\mathrm{PEF} \times \mathrm{BW} \times \mathrm{AT}} \\
\mathrm{CDI}_{\text {dermal }}=\frac{\mathrm{C} \times \mathrm{SA} \times \mathrm{AF} \times \mathrm{ABF} \times \mathrm{EF} \times \mathrm{ED} \times \mathrm{CF}}{\mathrm{BW} \times \mathrm{AT}}
\end{gathered}
$$

\begin{tabular}{|c|c|c|c|c|c|}
\hline \multirow[t]{2}{*}{ Variable } & \multirow[t]{2}{*}{ Explanation } & \multicolumn{2}{|c|}{ Value } & \multirow[t]{2}{*}{ Units } & \multirow[t]{2}{*}{ Reference } \\
\hline & & Adults & Children & & \\
\hline $\mathrm{C}$ & The total concentration of the PTE & & & $\mathrm{mg} / \mathrm{kg}$ & \\
\hline IngR & Ingestion rate of soil & 100 & 200 & mg/day & [74] \\
\hline InhR & Inhalation rate of soil & 20 & 7.63 & $\mathrm{~m}^{3} /$ day & [74] \\
\hline $\mathrm{EF}$ & Exposure frequency & 350 & 350 & day/year & [74] \\
\hline ED & Exposure duration & 24 & 6 & year & [74] \\
\hline BW & Body weight & 70 & 20 & $\mathrm{~kg}$ & [82] \\
\hline $\mathrm{AT}_{\mathrm{nc}}$ & The average time (non-carcinogenic risk) & $365 \times 24$ & $365 \times 6$ & days & [74] \\
\hline $\mathrm{AT}_{\mathrm{C}}$ & The average time (carcinogenic risk) & $365 \times 70$ & $365 \times 70$ & days & [81] \\
\hline PEF & Particle emission factor & $1.36 \times 10^{9}$ & $1.36 \times 10^{9}$ & $\mathrm{~m}^{3} / \mathrm{kg}$ & [74] \\
\hline SA & Surface area of the skin that contacts the PTEs & 4350 & 1600 & $\mathrm{~cm}^{2}$ & [74] \\
\hline $\mathrm{AF}$ & Skin adherence factor & 0.7 & 0.2 & $\mathrm{mg} / \mathrm{cm}^{2}$ & [74] \\
\hline $\mathrm{ABF}$ & Dermal absorption factor & 0.001 & 0.001 & - & [74] \\
\hline $\mathrm{CF}$ & Conversion factor & $10^{-6}$ & $10^{-6}$ & - & [74] \\
\hline
\end{tabular}

Table 1. Exposure factors for human health risk assessment.

Note: In the case of $\mathrm{Cr}, 1 / 6$ of the total concentration was used in the risk calculations for both non-carcinogenic and carcinogenic risk $[83,84]$.

Non-carcinogenic hazards are typically characterized by the hazard quotient (HQ). The $\mathrm{HQ}$ is defined as the quotient of the chronic daily intake divided by the toxicity threshold value, which is referred to as the reference dose $\left(R_{f} D\right)$ of a specific PTE. The HQ of a single PTE is determined by Equation (9). Equation (10) was used to analyze the health risk related to PTE exposure for carcinogenic risk [80]. The $R_{f} D$ and slope factor (SF) through each PTE exposure route are listed in Table 2.

$$
\begin{gathered}
\mathrm{HQ}_{i}=\frac{\mathrm{CDI}_{i}}{R_{f} D_{i}} \\
\mathrm{CR}_{i}=\mathrm{CDI}_{i} \times \mathrm{SF}_{i}
\end{gathered}
$$

where the subscript " $i$ " in Equations (9) and (10) indicate the three main PTE intake routes: ingestion, inhalation, and dermal contact. Only $\mathrm{As}, \mathrm{Cd}, \mathrm{Cr}, \mathrm{Ni}$, and $\mathrm{Pb}$ were calculated for the carcinogenic risk of the $\mathrm{SF}$ is given. 
Table 2. The reference dose and slope factor for each PTE and exposure way.

\begin{tabular}{|c|c|c|c|c|c|c|c|}
\hline Exposure Way & $R_{f} D_{\text {ingestion }}$ & $\mathbf{R}_{\mathbf{f}} \mathbf{D}_{\text {inhalation }}$ & $R_{f} D_{\text {dermal }}$ & $\mathrm{SF}_{\text {ingestion }}$ & $\mathrm{SF}_{\text {inhalation }}$ & $\mathrm{SF}_{\text {dermal }}$ & References \\
\hline As & 0.0003 & 0.000301 & 0.000123 & 1.5 & 15 & 3.66 & [85] \\
\hline $\mathrm{Cd}$ & 0.001 & 0.001 & 0.00001 & - & 6.3 & - & [85] \\
\hline $\mathrm{Cr}$ & 0.003 & 0.0000286 & 0.00006 & 0.5 & 42 & - & [85] \\
\hline $\mathrm{Cu}$ & 0.04 & 0.0402 & 0.012 & - & - & - & [85] \\
\hline $\mathrm{Hg}$ & 0.0003 & 0.000024 & 0.0003 & - & - & - & [85] \\
\hline $\mathrm{Ni}$ & 0.02 & 0.0201 & 0.0054 & - & 0.84 & - & [85] \\
\hline $\mathrm{Pb}$ & 0.0035 & 0.00352 & 0.000525 & - & 0.0042 & - & [74] \\
\hline $\mathrm{Zn}$ & 0.3 & 0.3 & 0.06 & - & - & - & [85] \\
\hline
\end{tabular}

Note: "_ not available.

For an individual PTE in soil, the possible non-carcinogenic and carcinogenic risks are expressed as the hazard index (HI) and total cancer risk (TCR). HI is the sum of the HQ of an individual PTE through the three intake routes. TCR is the sum of the CR through the three intake routes. The Equations. for the calculations are listed below:

$$
\begin{aligned}
& \mathrm{HI}=\mathrm{HQ}_{\text {ingestion }}+\mathrm{HQ}_{\text {inhalation }}+\mathrm{HQ}_{\text {dermal }} \\
& \mathrm{TCR}=\mathrm{CR}_{\text {ingestion }}+\mathrm{CR}_{\text {inhalation }}+\mathrm{CR}_{\text {dermal }}
\end{aligned}
$$

However, because HI and TCR refer to the risks of a single PTE, their cumulative values were calculated to provide a more complete picture; this shows the entire impact of all PTEs across all exposure pathways. The cumulative hazard index (CHI) and cumulative total cancer risk are calculated using the following Equations [86]:

$$
\begin{aligned}
\mathrm{CHI} & =\sum \mathrm{HI} \\
\mathrm{CTCR} & =\sum \mathrm{TCR}
\end{aligned}
$$

If $\mathrm{HI} \leq 1$, there is no significant risk of non-carcinogenic effects, and the magnitude of risk increases as $\mathrm{HI}$ increases; $\mathrm{HI}>1$ is thought to represent a significant risk of noncarcinogenic effects [82]. CR $<10^{-6}$ is considered to be negligible; $10^{-6}<\mathrm{CR}<10^{-4}$ represents an acceptable risk that is under control; $\mathrm{CR}>10^{-4}$ is considered unacceptable [80].

\subsection{Data Statistical Analysis and Mapping}

The descriptive statistics of PTEs such as minimum value, maximum value, mean value, the median, and standard deviation (SD) were conducted by SPSS 21.0 (IBM, Armonk, NY, USA). ArcMap ${ }^{\mathrm{TM}} 10.2$ (Esri Inc., Redlands, CA, USA) was used to examine the spatial distribution pattern and variability of the PTE contamination statues, ecological risk, and health risk.

\section{Results and Discussion}

\subsection{Concentration of PTEs in Soils of the Study Area}

Table 3 shows the descriptive statistics of the analyzed PTE concentrations and $\mathrm{pH}$ values of the collected surface soils from the Baoshan area, as well as local, regional, national, and relevant reference guideline values. The $\mathrm{pH}$ values of the surface soils from the research area ranged from 4.13 to 8.33 (median: 6.46; mean: 6.45). The registered median values for the concentrations of $\mathrm{As}, \mathrm{Cd}, \mathrm{Cr}, \mathrm{Cu}, \mathrm{Hg}, \mathrm{Ni}, \mathrm{Pb}$, and $\mathrm{Zn}$ were 16, 0.19, $113,41,0.10,51,34$, and $100 \mathrm{mg} / \mathrm{kg}$, respectively. All PTEs were above their national background values. The registered median values for the concentrations of $\mathrm{As}, \mathrm{Cd}, \mathrm{Cr}$, $\mathrm{Cu}, \mathrm{Hg}, \mathrm{Ni}, \mathrm{Pb}$, and $\mathrm{Zn}$ were 1.78, 1.73, 2.26, 2.16, 5.56, 2.32, 1.62, and 1.67 times higher than their corresponding national background values, respectively [87]. With the exception of $\mathrm{Pb}$, all of the studied PTEs were above their regional background values (background values of Yunnan province) [88]. In particular, the median values of the $\mathrm{Cd}, \mathrm{Hg}$, and $\mathrm{Cr}$ concentrations were 2.29, 2.00, and 1.66 times higher than their corresponding regional 
background values, respectively. However, no noticeable enrichments ( $>1.5$ times) or deficits ( $<0.8$ times) were identified when compared to the local background values of the studied PTEs [54]. When the PTE contents in the surface soil from the Baoshan area were compared to those found in the Australian surface soil [89], the American soil A layer [90], and the surface soil of the European continent [91] (Table 3), the contents of the PTEs in the surface soil of the study area were about 1.5 times higher or more than those in the surface soil of the American, Australian, and European continents. This fact indicates that the study area is a typical geological background area with high PTE levels, and the elevated PTE concentrations in the surface soil are mainly due to geological genesis [54]. The PTE contents in the surface soil of the study area are similar to those in the Sacramento Valley of Northern California, USA [60]. This area is similar to the Baoshan area, which is widely characterized with ultra-basic rocks and mineral deposits (such as $\mathrm{As}, \mathrm{Hg}, \mathrm{Zn}, \mathrm{Cu}, \mathrm{Au}$, and $\mathrm{Ag}$ ) [60]. The concentrations of $\mathrm{As}, \mathrm{Cd}, \mathrm{Cu}, \mathrm{Hg}, \mathrm{Pb}$, and $\mathrm{Zn}$ in the surface soil collected from the study area were significantly lower than those found in the soil around the mining areas in other research studies $[5,92]$ and in the surface soils deposited in areas with carbonate rocks as the main parent material [93]. Meanwhile, the $\mathrm{Cr}, \mathrm{Ni}$, and $\mathrm{Cu}$ concentrations in the present study area were determined to be significantly lower when compared to those in the surface soil in areas where ultra-basic rocks are the main parent materials [94].

Table 3. Descriptive statistics of PTEs in the surface soil of the study area and the local, regional, and national background values and related guidelines.

\begin{tabular}{|c|c|c|c|c|c|c|c|c|c|}
\hline Parameters & $\begin{array}{c}\text { As } \\
(\mathrm{mg} / \mathrm{kg})\end{array}$ & $\begin{array}{c}\mathrm{Cd} \\
(\mathrm{mg} / \mathrm{kg})\end{array}$ & $\begin{array}{c}\mathrm{Cr} \\
(\mathrm{mg} / \mathrm{kg})\end{array}$ & $\begin{array}{c}\mathrm{Cu} \\
(\mathrm{mg} / \mathrm{kg})\end{array}$ & $\underset{(\mathrm{mg} / \mathrm{kg})}{\mathrm{Hg}}$ & $\begin{array}{c}\mathrm{Ni} \\
(\mathrm{mg} / \mathrm{kg})\end{array}$ & $\begin{array}{c}\mathrm{Pb} \\
(\mathrm{mg} / \mathrm{kg})\end{array}$ & $\begin{array}{c}\mathrm{Zn} \\
(\mathrm{mg} / \mathrm{kg})\end{array}$ & $\mathrm{pH}$ \\
\hline Depths (cm) & $0-20$ & $0-20$ & $0-20$ & $0-20$ & $0-20$ & $0-20$ & $0-20$ & $0-20$ & $0-20$ \\
\hline $\mathrm{N}$ & 1574 & 1574 & 1574 & 1574 & 1574 & 1574 & 1574 & 1574 & 1574 \\
\hline Mean & 23 & 0.27 & 128 & 49 & 0.18 & 58 & 45 & 115 & 6.45 \\
\hline 25 th & 10 & 0.14 & 91 & 32 & 0.07 & 40 & 27 & 84 & 5.5 \\
\hline Median & 16 & 0.19 & 113 & 41 & 0.1 & 51 & 34 & 100 & 6.46 \\
\hline 75 th & 27 & 0.28 & 151 & 58 & 0.17 & 70 & 43 & 121 & 7.38 \\
\hline Min & 0.5 & 0.02 & 10 & 3.12 & 0 & 3.68 & 4.42 & 28 & 4.13 \\
\hline Max & 909 & 5.35 & 422 & 652 & 6.81 & 361 & 2106 & 1943 & 8.33 \\
\hline Standard deviation & 31.21 & 364.21 & 53.3 & 32.43 & 377.59 & 28 & 93.48 & 93.76 & 1.05 \\
\hline Variance & 973.78 & $132,646.72$ & 2841.27 & 1051.42 & $142,577.16$ & 772.12 & 8737.68 & 8791.49 & 1.1 \\
\hline Skewness & 15.83 & 7.92 & 1.32 & 7.51 & 10.68 & 2.17 & 16.07 & 11.74 & -0.07 \\
\hline Kurtosis & 417.65 & 83.5 & 2.18 & 108.21 & 145.11 & 12.34 & 298.38 & 185.29 & -1.2 \\
\hline Local background a & 19 & 0.13 & 119 & 45 & 0.11 & 58 & 31 & 100 & 6.57 \\
\hline Regional background ${ }^{b}$ & 15.6 & 0.083 & 67.9 & 35.1 & 0.05 & 40.9 & 37.1 & 88.4 & - \\
\hline National background $^{\mathrm{c}}$ & 9 & 0.11 & 50 & 19 & 0.018 & 22 & 21 & 60 & 8.1 \\
\hline Australian surface soil d & 1.6 & 0.04 & 23.6 & 11.2 & 0.01 & 9.8 & 7.22 & 26.1 & - \\
\hline American soil A layer ${ }^{\mathrm{e}}$ & 5.2 & 0.02 & 31 & 14.8 & 0.02 & 13.8 & 17.8 & 59 & - \\
\hline Surface soil of Europe $\mathrm{f}^{\mathrm{f}}$ & 7.03 & 0.145 & 60 & 13 & 0.037 & 18 & 22.6 & 52 & 5.51 \\
\hline $\begin{array}{c}\text { Surface soil of Sacramento Valley northern } \\
\text { California } \mathrm{g}\end{array}$ & 6 & 0.2 & 96 & 37 & - & 50 & 23 & 88 & - \\
\hline $\begin{array}{c}\text { Surface soils of Mouriki-Thiva Area (Central } \\
\text { Greece) }^{h}\end{array}$ & - & - & 0.237 & 31 & - & 1549 & 23 & 63 & - \\
\hline Surface soil from 72 examined mines of China ${ }^{i}$ & 195.5 & 11 & 84.28 & 211.9 & 3.82 & 106.6 & 641.3 & 1163 & - \\
\hline Surface soil near $\mathrm{Pb}-\mathrm{Zn}$ mine $\mathrm{j}^{\mathrm{j}}$ & 31.67 & 0.597 & 77.57 & 0.065 & 680 & 37.69 & 362 & 486 & - \\
\hline \multirow[t]{2}{*}{ Surface soil Guangxi Hengxian k } & 75.8 & 1.91 & 467.0 & 48.5 & 0.21 & 76.2 & 84.2 & 258.2 & 6.1 \\
\hline & 30 & 0.3 & 150 & 50 & 0.5 & 60 & 70 & 200 & $\mathrm{pH} \leq 5.5$ \\
\hline \multirow{4}{*}{ RSV of China ${ }^{1}$} & 30 & 0.3 & 150 & 50 & 0.5 & 70 & 90 & 200 & $5.5<\mathrm{p} \overline{\mathrm{H}} \leq 6.5$ \\
\hline & 25 & 0.3 & 200 & 100 & 0.6 & 100 & 120 & 200 & $6.5<\mathrm{pH} \leq 7.5$ \\
\hline & 20 & 0.6 & 250 & 100 & 1 & 190 & 170 & 300 & $\mathrm{pH}>7.5$ \\
\hline & 200 & 1.5 & 800 & - & 2 & - & 400 & - & $\mathrm{pH} \leq 5.5$ \\
\hline \multirow{3}{*}{ RIV of China ${ }^{m}$} & 150 & 2 & 850 & - & 2.5 & - & 500 & - & $5.5<p \bar{H} \leq 6.5$ \\
\hline & 120 & 3 & 1000 & - & 4 & - & 700 & - & $6.5<\mathrm{pH} \leq 7.5$ \\
\hline & 100 & 4 & 130 & - & 6 & - & 1000 & - & $\mathrm{pH}>7.5$ \\
\hline
\end{tabular}

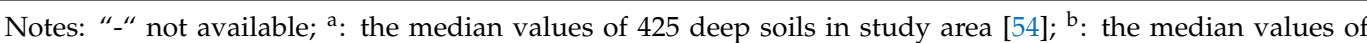
deep soil of Yunnan province [88]; ${ }^{c}$ : the median value of deep soil of China geochemical baseline project [87]; d: reference from [89]; e: reference from [90]; f: reference from [91]; g: reference from [60]; ${ }^{\text {h: }}$ reference from [94]; ${ }^{\mathrm{i}}$ : reference from [5]; ${ }^{\mathrm{j}}$ : reference from [92]; : reference from [93]; ${ }^{1}$ : the risk screening values for soil contamination of agricultural land of China [95]; ${ }^{\mathrm{m}}$ : the risk intervention values for soil contamination of agricultural land of China [95].

\subsection{Soil Quality Assessment}

\subsubsection{Comparison to National Agricultural Land Risk Control Standard Values}

The number of sites and the percentage from which the collected surface soils registered values of PTEs ( $\mathrm{As}, \mathrm{Cd}, \mathrm{Cr}, \mathrm{Cu}, \mathrm{Hg}, \mathrm{Ni}, \mathrm{Pb}$, and $\mathrm{Zn}$ ) that exceeded the risk screening 
values (RSV) and risk intervention values (RIV) for soil environmental quality-risk control standards for soil contamination of agricultural land in China-are listed in Table 4. If the concentration of a PTE in agriculture land soil is lower than or equal to the concentration of RSV, then the ecological risk of this PTE in the soil is low, whereas if the concentration of a PTE in agriculture land soil is higher than the RSV, then the ecological risk for this PTE in agricultural soil is high. In the latter case, the soil should be environmentally monitored. If the concentration of PTE is higher than the RIV, strict intervention and controls should be taken [95].

Table 4. The number and percentage of sites over the national environmental quality of PTEs.

\begin{tabular}{ccccccccccc}
\hline & & As & Cd & Cr & Cu & Hg & Ni & Pb & Zn & PTEs \\
\hline \multirow{2}{*}{$<$ RSV } & number & 1147 & 1291 & 1353 & 1311 & 1514 & 1388 & 1511 & 1522 & 805 \\
& percentage & $72.87 \%$ & $82.02 \%$ & $85.96 \%$ & $83.29 \%$ & $96.19 \%$ & $88.18 \%$ & $96.00 \%$ & $96.70 \%$ & $51.14 \%$ \\
\multirow{2}{*}{ RSV-RIV } & number & 415 & 274 & 221 & 263 & 56 & 186 & 57 & 52 & 743 \\
& percentage & $26.37 \%$ & $17.41 \%$ & $14.04 \%$ & $16.71 \%$ & $0.25 \%$ & $11.82 \%$ & $3.30 \%$ & $3.30 \%$ & $47.20 \%$ \\
\multirow{2}{*}{$>$ RIV } & number & 12 & 9 & 0 & 0 & 0 & 0 & 6 & 0 & 26 \\
& percentage & $76.00 \%$ & $0.57 \%$ & $0.00 \%$ & $0.00 \%$ & $0.00 \%$ & $0.00 \%$ & $0.38 \%$ & $0.00 \%$ & $1.65 \%$ \\
\hline
\end{tabular}

Notes: RSV, the risk screening values for soil contamination of agricultural land of China [95]; RIV, the risk intervention values for soil contamination of agricultural land of China [95].

The results showed that the PTEs in certain surface soil sites in the study area exceed the RSV. The site percentage of surface soils with values that exceeded the RSV were as follows: As (26.37\%), Cd (17.41\%), Cu (16.71\%), Cr (14.04\%), Ni (11.8\%), Pb (3.30\%), Zn $(3.3 \%)$, and $\mathrm{Hg}(0.25 \%)$ (Table 4$)$. In case of the RIV values, only a few sites with As, Cd, and $\mathrm{Pb}$ were above the limit. The site percentage of surface soils with values exceeding the RSV were as follows: As $(0.76 \%), \mathrm{Cd}(0.57 \%)$, and $\mathrm{Pb}(0.38 \%)$. To demonstrate the distribution of PTEs at an environmental quality level, figures are plotted by assigning the sample site values to $2 \mathrm{~km} \times 2 \mathrm{~km}$ grids (this is the sample analysis density). The spatial distribution of the sites with $\mathrm{Cr}, \mathrm{Ni}$, and $\mathrm{Cu}$ values that were higher than the RSV and RIV corresponds to the basalt and carbonatite distribution in the studied area. The spatial distribution of the samples with $\mathrm{Cu}, \mathrm{Pb}$, and $\mathrm{Cd}$ concentrations exceeding the RSV and RIV is compatible with the distribution of $\mathrm{Cu}-\mathrm{Pb}-\mathrm{Zn}$ deposits and a portion of the carbonatite rock distribution. The distribution of the sites with As and $\mathrm{Hg}$ concentrations exceeding the RSV and RIV is compatible with the distribution of $\mathrm{Hg}$ and $\mathrm{Cu}-\mathrm{Pb}-\mathrm{Zn}$ deposits, as well as a portion of the carbonatite rock distribution (Figure 2). This finding shows that soils formed from basalt and carbonatite rocks, as well as ore parent materials or those that are formed near mining areas, have higher PTE concentrations [2,33-37,54,55,57,60,62].

\subsubsection{Evaluation by Pollution Indices}

The values and descriptive statistics of the selected pollution indices are shown in Table 5. For this study, we used Sc as the reference element because of its abundance and stability in the upper continental crust, its uniformity across the entirety of the study area, and its effective use in prior studies [94,96,97]. 

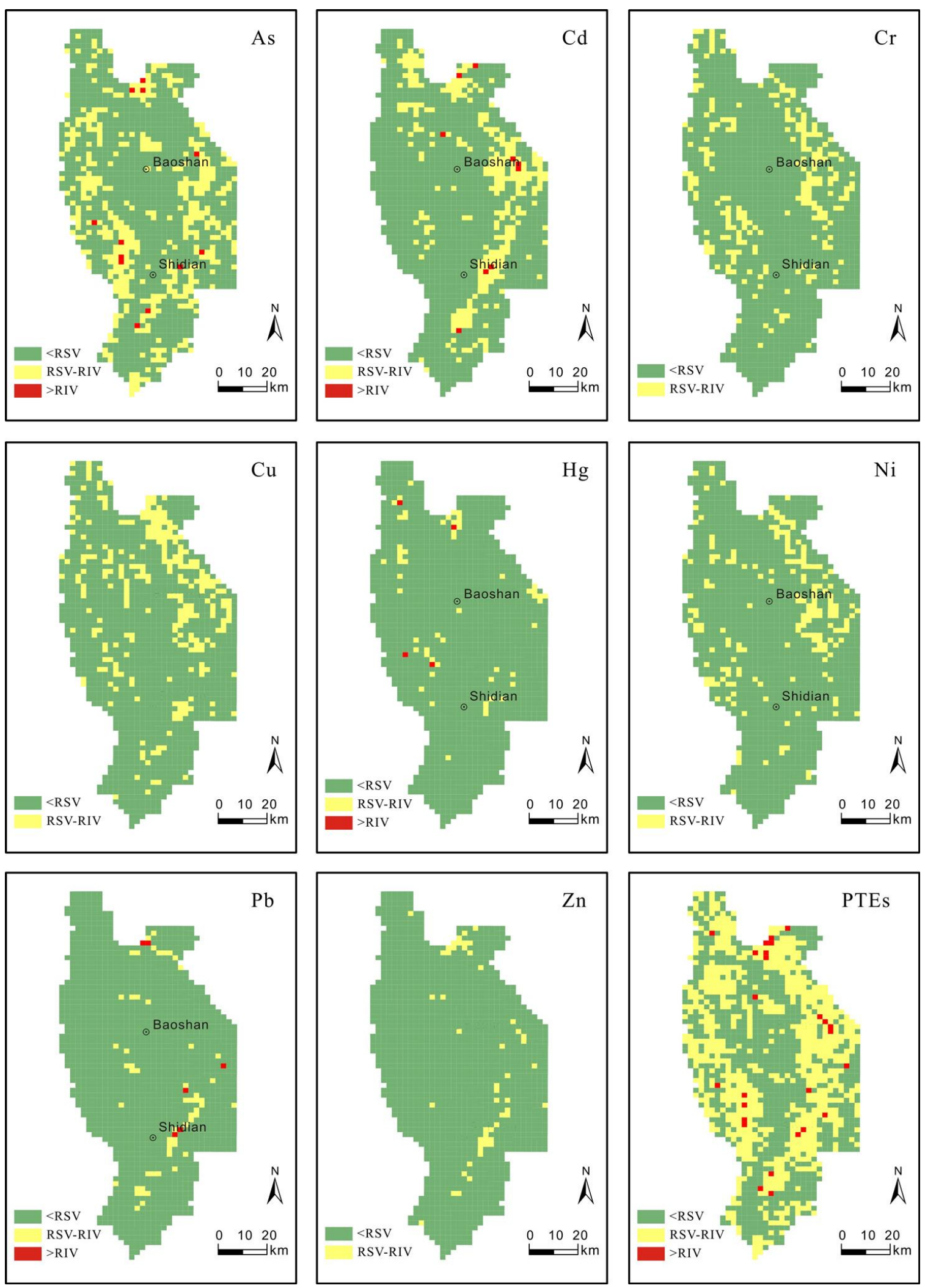

Figure 2. The distribution of soil environmental quality based on the risk control standard for soil contamination of agricultural land of China. 
Table 5. Descriptive statistics of the environmental and ecological risk assessment of PTEs in the examined soils using the enrichment factor $(\mathrm{EF})$, geo-accumulation index $\left(\mathrm{I}_{\text {geo }}\right)$, contamination factor $\left(\mathrm{C}_{\mathrm{f}}\right)$, ecological risk index $\left(E_{r}^{i}\right)$, and potential ecological risk (PERI).

\begin{tabular}{|c|c|c|c|c|c|c|c|c|c|}
\hline & \multicolumn{8}{|c|}{ EF } & \\
\hline & As & $\mathrm{Cd}$ & $\mathrm{Cr}$ & $\mathrm{Cu}$ & $\mathrm{Hg}$ & $\mathrm{Ni}$ & $\mathrm{Pb}$ & $\mathrm{Zn}$ & \\
\hline Mean & 1.32 & 2.14 & 1.07 & 1.08 & 1.70 & 1.00 & 1.62 & 1.21 & \\
\hline 25 th & 0.62 & 1.09 & 0.95 & 0.88 & 0.62 & 0.85 & 0.93 & 0.90 & \\
\hline Median & 0.96 & 1.56 & 1.05 & 1.00 & 1.01 & 0.95 & 1.31 & 1.10 & \\
\hline 75 th & 1.52 & 2.30 & 1.16 & 1.15 & 1.74 & 1.10 & 1.68 & 1.33 & \\
\hline Min & 0.01 & 0.35 & 0.28 & 0.23 & 0.04 & 0.29 & 0.07 & 0.32 & \\
\hline Max & 49.51 & 32.14 & 3.14 & 16.06 & 75.48 & 5.54 & 62.66 & 17.47 & \\
\hline $\begin{array}{l}\text { Standard } \\
\text { deviation }\end{array}$ & 1.73 & 2.50 & 0.21 & 0.68 & 3.51 & 0.29 & 3.03 & 0.85 & \\
\hline Variance & 3.01 & 6.23 & 0.04 & 0.46 & 12.34 & 0.08 & 9.19 & 0.72 & \\
\hline Skewness & 15.02 & 6.56 & 1.47 & 13.97 & 11.62 & 4.74 & 15.35 & 10.54 & \\
\hline \multirow[t]{3}{*}{ Kurtosis } & 384.02 & 58.43 & 9.34 & 252.40 & 185.17 & 55.95 & 274.19 & 160.46 & \\
\hline & \multicolumn{8}{|c|}{$\mathrm{I}_{\text {geo }}$} & \\
\hline & As & $\mathrm{Cd}$ & $\mathrm{Cr}$ & $\mathrm{Cu}$ & $\mathrm{Hg}$ & $\mathrm{Ni}$ & $\mathrm{Pb}$ & $\mathrm{Zn}$ & \\
\hline Mean & -0.75 & 0.05 & -0.60 & -0.65 & -0.60 & -0.73 & -0.38 & -0.54 & \\
\hline 25 th & -1.47 & -0.53 & -0.97 & -1.08 & -1.34 & -1.11 & -0.76 & -0.83 & \\
\hline Median & -0.78 & -0.07 & -0.66 & -0.74 & -0.68 & -0.76 & -0.45 & -0.58 & \\
\hline 75th & -0.07 & 0.52 & -0.24 & -0.24 & 0.03 & -0.31 & -0.09 & -0.31 & \\
\hline Min & -5.81 & -3.71 & -4.16 & -4.44 & -5.44 & -4.56 & -3.38 & -2.42 & \\
\hline Max & 5.02 & 4.77 & 1.24 & 3.27 & 5.34 & 2.06 & 5.52 & 3.69 & \\
\hline $\begin{array}{l}\text { Standard } \\
\text { deviation }\end{array}$ & 1.10 & 0.94 & 0.58 & 0.68 & 1.19 & 0.65 & 0.76 & 0.56 & \\
\hline Variance & 1.21 & 0.88 & 0.34 & 0.47 & 1.42 & 0.43 & 0.58 & 0.31 & \\
\hline Skewness & 0.15 & 0.97 & -0.26 & 0.17 & 0.75 & -0.28 & 1.79 & 1.50 & \\
\hline \multirow[t]{3}{*}{ Kurtosis } & 1.02 & 2.88 & 2.50 & 3.23 & 2.21 & 1.75 & 10.42 & 8.34 & \\
\hline & \multicolumn{8}{|c|}{$C_{f}$} & \\
\hline & As & $\mathrm{Cd}$ & $\mathrm{Cr}$ & $\mathrm{Cu}$ & $\mathrm{Hg}$ & $\mathrm{Ni}$ & $\mathrm{Pb}$ & $\mathrm{Zn}$ & \\
\hline Mean & 1.23 & 2.06 & 1.07 & 1.08 & 1.58 & 1.00 & 1.47 & 1.14 & \\
\hline 25th & 0.54 & 1.04 & 0.77 & 0.71 & 0.59 & 0.69 & 0.88 & 0.84 & \\
\hline Median & 0.87 & 1.43 & 0.95 & 0.90 & 0.93 & 0.88 & 1.10 & 1.00 & \\
\hline 75th & 1.43 & 2.15 & 1.27 & 1.27 & 1.53 & 1.21 & 1.41 & 1.21 & \\
\hline Min & 0.03 & 0.11 & 0.08 & 0.07 & 0.03 & 0.06 & 0.14 & 0.28 & \\
\hline Max & 48.53 & 40.98 & 3.54 & 14.43 & 60.66 & 6.25 & 68.72 & 19.38 & \\
\hline $\begin{array}{l}\text { Standard } \\
\text { deviation }\end{array}$ & 1.67 & 2.79 & 0.45 & 0.72 & 3.36 & 0.48 & 3.05 & 0.94 & \\
\hline Variance & 2.77 & 7.78 & 0.20 & 0.51 & 11.30 & 0.23 & 9.30 & 0.87 & \\
\hline Skewness & 15.83 & 7.92 & 1.32 & 7.51 & 10.68 & 2.17 & 16.07 & 11.74 & \\
\hline \multirow[t]{3}{*}{ Kurtosis } & 417.65 & 83.50 & 2.18 & 108.21 & 145.11 & 12.34 & 298.38 & 185.29 & \\
\hline & \multicolumn{8}{|c|}{$E_{r}^{i}$} & \multirow{2}{*}{ PERI } \\
\hline & As & $\mathrm{Cd}$ & $\mathrm{Cr}$ & $\mathrm{Cu}$ & $\mathrm{Hg}$ & $\mathrm{Ni}$ & $\mathrm{Pb}$ & $\mathrm{Zn}$ & \\
\hline Mean & 12.30 & 61.89 & 2.14 & 5.39 & 63.39 & 5.01 & 7.37 & 1.14 & 158.63 \\
\hline 25 th & 5.43 & 31.27 & 1.53 & 3.54 & 23.72 & 3.47 & 4.42 & 0.84 & 84.95 \\
\hline Median & 8.75 & 42.97 & 1.90 & 4.50 & 37.35 & 4.42 & 5.50 & 1.00 & 113.35 \\
\hline 75th & 14.31 & 64.36 & 2.54 & 6.37 & 61.17 & 6.04 & 7.04 & 1.21 & 166.27 \\
\hline Min & 0.27 & 3.45 & 0.17 & 0.35 & 1.38 & 0.32 & 0.72 & 0.28 & 23.34 \\
\hline Max & 485.25 & 1229.28 & 7.09 & 72.16 & 2426.50 & 31.27 & 343.60 & 19.38 & 2548.42 \\
\hline $\begin{array}{l}\text { Standard } \\
\text { deviation }\end{array}$ & 16.66 & 83.66 & 0.90 & 3.59 & 134.49 & 2.41 & 15.25 & 0.94 & 185.89 \\
\hline Variance & 277.45 & 6998.91 & 0.80 & 12.87 & $18,086.25$ & 5.79 & 232.49 & 0.87 & $34,554.84$ \\
\hline Skewness & 15.83 & 7.92 & 1.32 & 7.51 & 10.68 & 2.17 & 16.07 & 11.74 & 6.72 \\
\hline Kurtosis & 417.65 & 83.50 & 2.18 & 108.21 & 145.11 & 12.34 & 298.38 & 185.29 & 59.60 \\
\hline
\end{tabular}


There was no significant enrichment or contamination with the studied PTEs in the surface soils in the study area, based on the average (mean) and median values of EF, $\mathrm{I}_{\text {geo, }}$ and $\mathrm{C}_{\mathrm{f}}$ that were obtained (Table 5). With the exception of $\mathrm{Cr}$, the rest of the PTEs studied in this area showed significant to extremely high enrichment by the indicated EF in some locations. Of the elements with EF values that were $>5,2.16 \%$ (34 sites) of As, 4.51\% (71 sites) of $\mathrm{Cd}, 0.44 \%$ (7 sites) of $\mathrm{Cu}, 4.00 \%$ (63 sites) of $\mathrm{Hg}, 0.06 \%$ (only 1 site) of $\mathrm{Ni}, 1.97 \%$ (31 sites) of $\mathrm{Pb}$, and $0.64 \%$ (10 sites) of $\mathrm{Zn}$, these were classified as having a significant contamination or higher level. Specifically, the maximum EF values of As (49.51), Cd (32.14), $\mathrm{Cu}$ (16.06), $\mathrm{Hg}$ (75.48), Ni (5.54), Pb (62.66), and Zn (17.47) were examined. Similarly, $0.95 \%$ (15 sites) of As, 3.30\% (52 sites) of Cd, $0.25 \%$ (four sites) of Cu, $2.60 \%$ (41 sites) of $\mathrm{Hg}, 0.06 \%$ (one site) of $\mathrm{Ni}, 1.14 \%$ (18 sites) of $\mathrm{Pb}$, and $0.57 \%$ (nine sites) of $\mathrm{Zn}$ showed moderately to highly contaminated or higher levels, with $\mathrm{I}_{\text {geo }}$ values $>2$. The maximum $\mathrm{I}_{\text {geo }}$ values of As (5.02), Cd (4.77), Cu (3.27), $\mathrm{Hg}$ (5.34), Ni (2.06), Pb (5.52), and Zn (3.69) were examined. About 5.84\% (92 sites) of As, $12.77 \%$ (201 sites) of Cd, $0.19 \%$ (only three sites) of $\mathrm{Cr}, 0.76 \%$ (12 sites) of $\mathrm{Cu}, 8.07 \%$ (127 sites) of $\mathrm{Hg}, 0.25 \%$ (only four sites) of $\mathrm{Ni}$, $3.94 \%$ (62 sites) of $\mathrm{Pb}$, and 1.59\% (25 sites) of $\mathrm{Zn}$ showed considerable contamination or higher levels, with $\mathrm{C}_{\mathrm{f}}$ values $>3$. The maximum $\mathrm{C}_{\mathrm{f}}$ values of $\mathrm{As}$ (48.53), $\mathrm{Cd}(40.98), \mathrm{Cr}$ (3.54), $\mathrm{Cu}$ (14.43), $\mathrm{Hg}$ (60.66), Ni (6.25), Pb (68.72), and $\mathrm{Zn}$ (19.38) were also determined. Contour maps using inverse distance-weighted (IDW) interpolation were created to analyze the locations of the contaminated PTEs and their affected region, since IDW is a simple, intuitive, and efficient interpolation method and demonstrates good results when the distribution of the sample sites is uniform (Figures 3-5). The spatial distributions of $\mathrm{Cu}$, $\mathrm{Pb}$, and $\mathrm{Zn}$ with EF values $>5$ (significant contamination or higher levels) coincided with the $\mathrm{Cu}-\mathrm{Pb}-\mathrm{Zn}$ deposits. $\mathrm{Cd}$ showed a similar distribution pattern, but it also coincided with the carbonatite rock distribution. The distributions of As and $\mathrm{Hg}$ with EF values $>5$ are consistent with the distribution of the $\mathrm{Hg}$ and $\mathrm{Cu}-\mathrm{Pb}-\mathrm{Zn}$ deposits and a portion of carbonatite rocks (Figure 3). Similar distributions were found using $\mathrm{I}_{\text {geo }}$ and $\mathrm{C}_{\mathrm{f}}$ values (Figures 4 and 5).
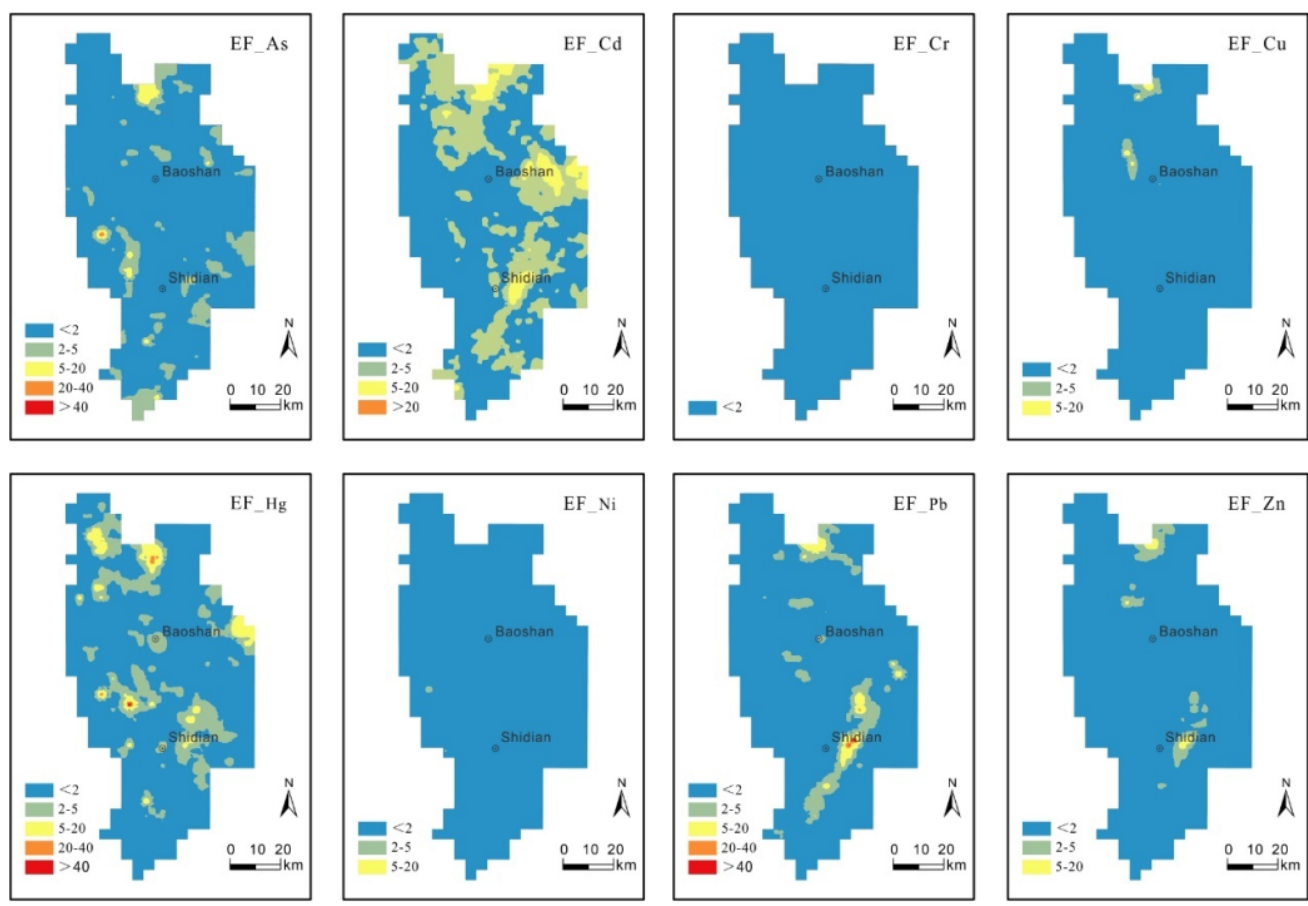

Figure 3. The distribution of counter maps of the enrichment factor (EF) determined by inverse distance-weighted (IDW) interpolation. 

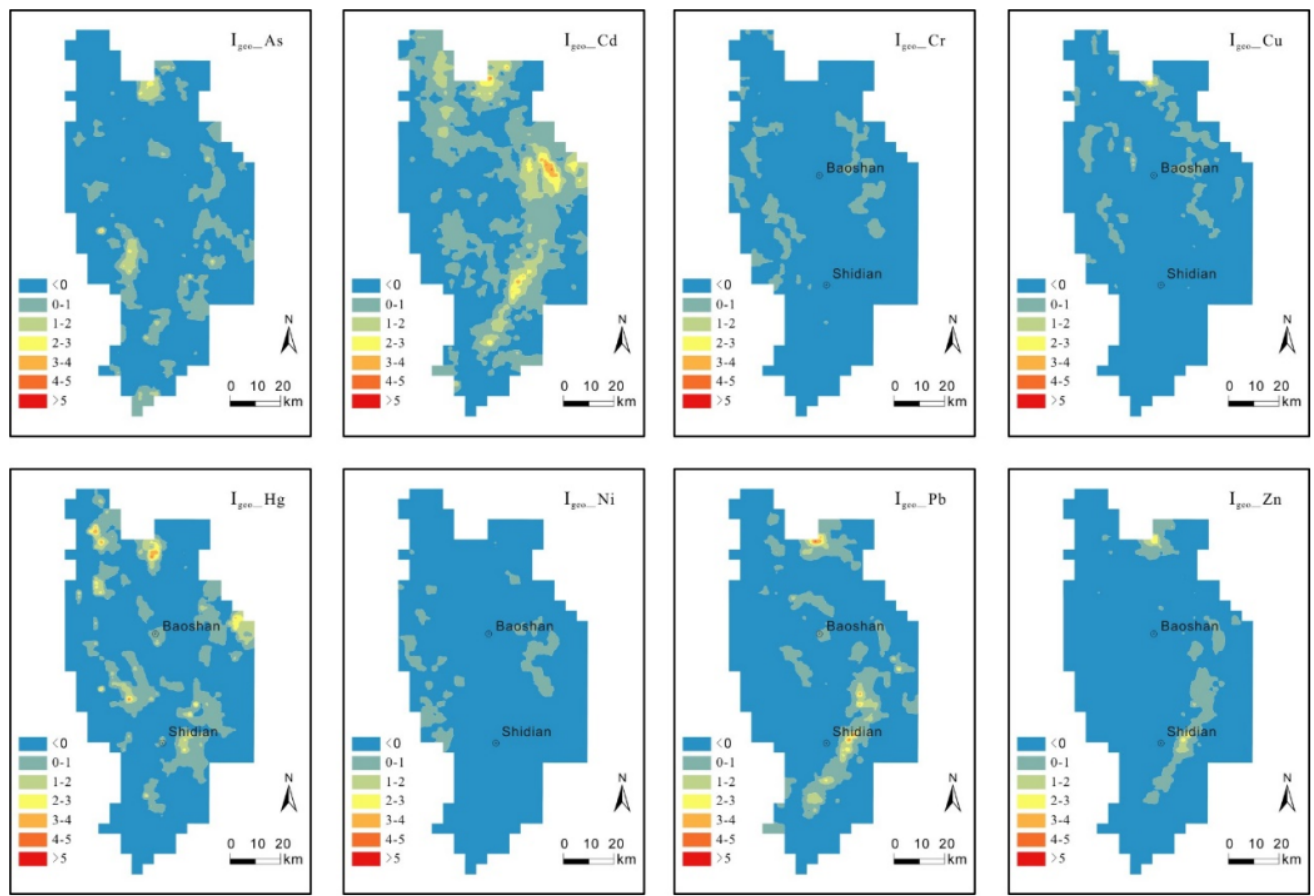

Figure 4. The distribution of counter maps of the geo-accumulation index ( $\left.\mathrm{I}_{\text {geo }}\right)$ determined by inverse distance-weighted (IDW) interpolation.
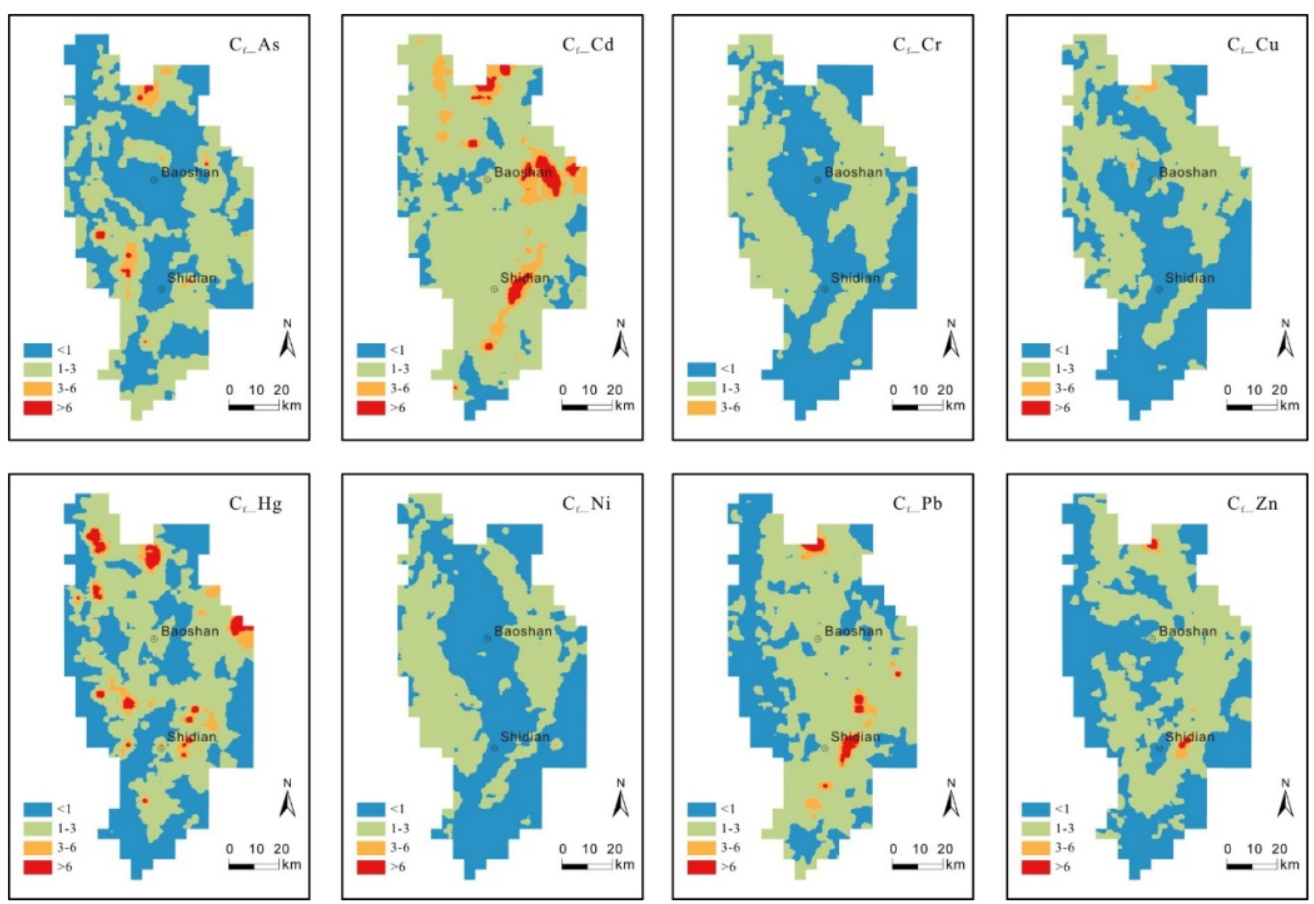

Figure 5. The distribution of counter maps of the contamination factor $\left(C_{f}\right)$ determined by inverse distance-weighted (IDW) interpolation.

\subsection{Assessing the Environmental Ecological Risks of the Surface Soil}

To assess the potential impact of a given PTE in the soil on ecosystems, $\left(E_{r}^{i}\right)$ was used in this study. The PTEs in the surface soil of the research area did not demonstrate a risk degree higher than "moderate risk" according to the average (mean) and median values $E_{r}^{i}$ obtained at all sampling sites. While $\mathrm{Cd}$ and $\mathrm{Hg}$ posed higher ecological risks when compared to the other PTEs by the upper quarter values, $\mathrm{Cd}$ and $\mathrm{Hg}$ showed examined 
values of 64.36 and 61.17 , respectively, due to the higher toxic response factor. Furthermore, the highest $E_{r}^{i}$ values of $\mathrm{Hg}$ (2426.50), $\mathrm{Cd}$ (1229.28), As (485.25), and $\mathrm{Pb}$ (343.60) were examined, due to their greater toxic response factors of $40,30,10$, and 5 when compared to $\mathrm{Cu}$ (five), $\mathrm{Ni}$ (five), $\mathrm{Cr}$ (two), and $\mathrm{Zn}$ (one), respectively. The environmental ecological risks of all of the studied PTEs can be ranked as: $\mathrm{Cd}>\mathrm{Hg}>\mathrm{As} \approx \mathrm{Pb}>\mathrm{Cr}=\mathrm{Ni}=\mathrm{Zn}$. Overall, $0.64 \%$ (10 sites) of As, $16.07 \%$ ( 253 sites) of $\mathrm{Cd}, 16.39 \%$ (258 sites) of $\mathrm{Hg}$, and $0.51 \%$ (eight sites) of $\mathrm{Pb}$ were shown to have $E_{r}^{i}$ values $>80$, and $7.05 \%$ (11 sites) of all of the studied PTEs with PERI values $>300$ were at or above the level of "considerable protentional ecological risk".

Contour maps determined by IDW interpolation were produced to discover the spatial distributions of the possible ecological risk of these studied PTEs (Figure 6). The distributions of $\mathrm{As}, \mathrm{Cd}, \mathrm{Hg}$, and $\mathrm{Pb}$, which had $E_{r}^{i}$ values $>80$ and PERI values $>300$, were compatible with the distribution of $\mathrm{Hg}$ and $\mathrm{Cu}-\mathrm{Pb}-\mathrm{Zn}$ deposits in the study area. The high PTE concentrations and their associated ecological risks in the soils surrounding $\mathrm{Hg}$ and $\mathrm{Cu}-\mathrm{Pb}-\mathrm{Zn}$ deposits have also been found by other researchers [5,52].
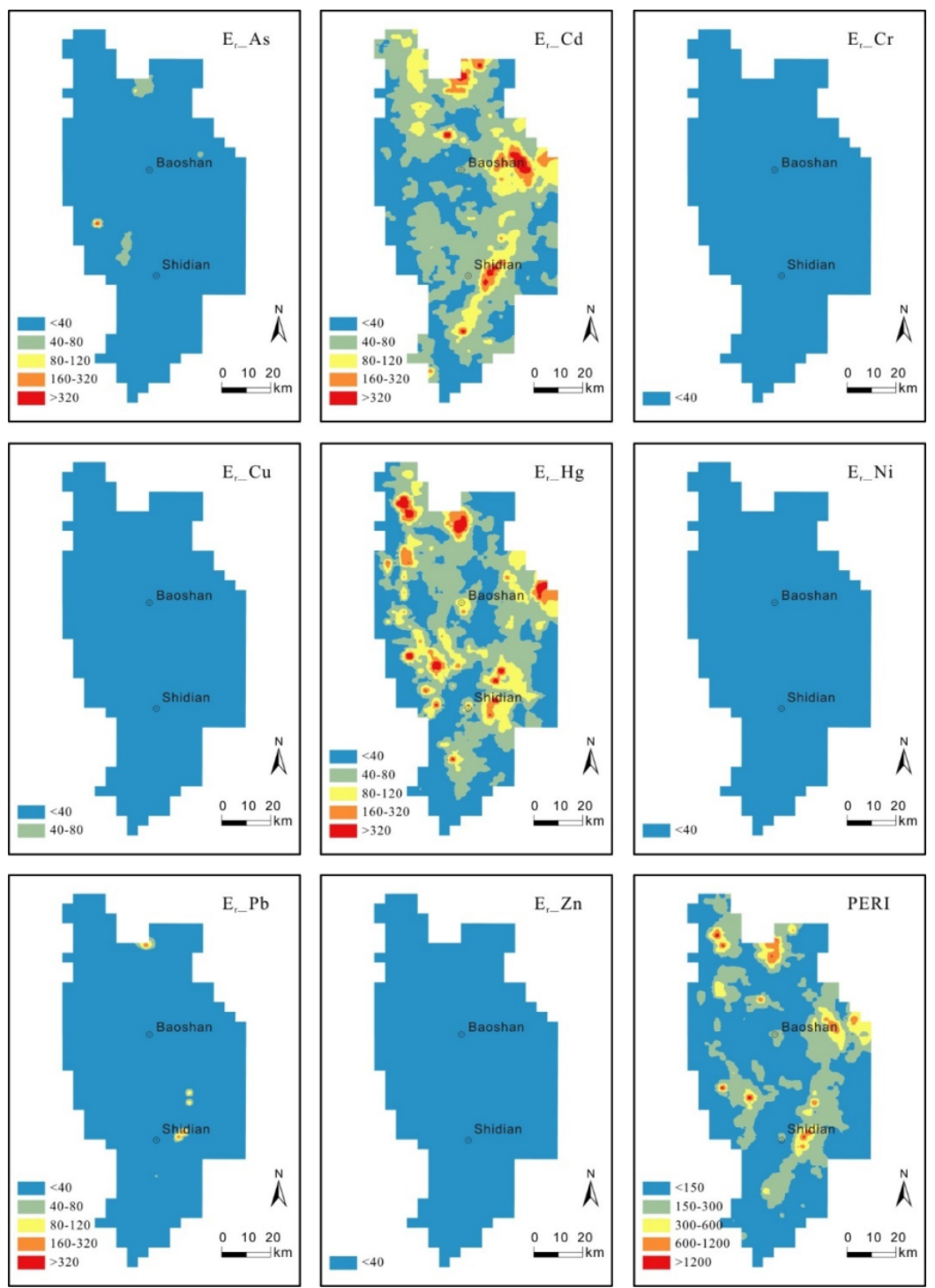

Figure 6. The distribution of counter maps of the potential ecological risk $\left(E_{r}^{i}\right)$ of a particular PTE and potential ecological risk index (PERI) of all of the studied PTEs determined by inverse distance weighted (IDW) interpolation. 


\subsection{Assessing the Health Risks Associated with the PTEs}

\subsubsection{Non-Carcinogenic Risks to Humans}

The median values of non-carcinogenic risk assessment indictors, such as CDI, HQ, $\mathrm{HI}$, and CHI are listed in Table 6.

Table 6. Median values of non-carcinogenic risk indictors to humans from soil PTEs.

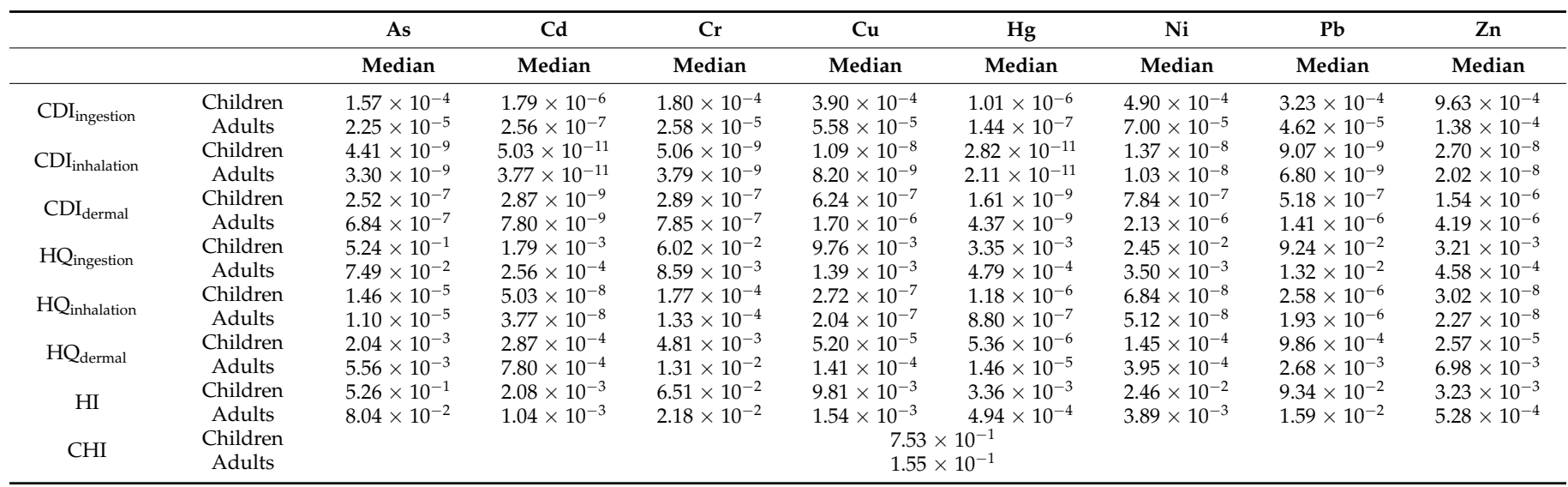

The median values of the non-carcinogenic CDI and HQ of all of the studied PTEs by direct oral ingestion were substantially higher when compared to those by dermal contact and respiratory inhalation. The median values of daily non-carcinogenic exposure and the health risks associated with the three different pathways were ranked as follows: $\mathrm{CDI}_{\text {ingestion }}>\mathrm{CDI}_{\text {dermal }}>\mathrm{CDI}_{\text {inhalation }}$ and $\mathrm{HQ}_{\text {ingestion }}>\mathrm{HQ}_{\text {dermal }}>\mathrm{HQ}_{\text {inhalation }}$. For children, the order of the median values of the non-carcinogenic risks of PTEs from the three pathways was as follows: $\mathrm{As}>\mathrm{Pb}>\mathrm{Cr}>\mathrm{Ni}>\mathrm{Cu}>\mathrm{Hg}>\mathrm{Zn}>\mathrm{Cr}$, while for adults it was As $>\mathrm{Cr}>\mathrm{Pb}>\mathrm{Ni}>\mathrm{Cu}>\mathrm{Cd}>\mathrm{Zn}>\mathrm{Hg}$. In the case of children, the non-carcinogenic health risks were higher than those in adults for all of the PTEs, with the exception of dermal contact, which has a lower non-carcinogenic daily exposure.

There were no identified non-carcinogenic risks for humans in case of the individual PTEs by the three pathways or by the sum of them, based on the median values, in either children or adults. However, the conclusions are not the same when we consider all sampling points in the research area. Through direct oral ingestion, the majority of the sites represent no significant risk of non-carcinogenic consequences for children and adults. While $19.38 \%$ (305 sites) of As and $0.51 \%$ (eight sites) of $\mathrm{Pb}$ pose a non-carcinogenic risk to children and $0.13 \%$ (two sites) of As pose a non-carcinogenic risk to adults through the direct oral ingestion pathway. For all of the pathways, 19.57\% (308 sites) of As and $0.51 \%$ (eight sites) of $\mathrm{Pb}$ pose non-carcinogenic risks for children and $0.25 \%$ (four sites) of As pose a non-carcinogenic risk for adults, respectively. All of the total studied PTEs through the three pathways pose non-carcinogenic risks for children and adults were $32.08 \%$ (505 sites) and $0.57 \%$ (nine sites), respectively. No sites, on the other hand, represented a non-carcinogenic risk to children and adults through inhalation or dermal contact (Table 7).

Figure 7 shows the distribution of the non-carcinogenic risk of PTEs to children and adults determined by IDW interpolation. The distribution of sites with significant noncarcinogenic risk to humans is in accordance with the distribution of the $\mathrm{Hg}$ and $\mathrm{Cu}-\mathrm{Pb}-\mathrm{Zn}$ deposits. Children are more vulnerable to environmental contaminants when compared to adults due to behavioral and physiological differences [98]. As poses the highest noncarcinogenic risk when compared to the other studied PTEs because it has the lowest non-carcinogenic daily intake reference dose permitted by oral ingestion. 
Table 7. The number of sites (percentage) of non-carcinogenic risk levels to humans from soil PTEs.

\begin{tabular}{|c|c|c|c|c|c|c|c|c|c|c|}
\hline & & & As & $\mathrm{Cd}$ & $\mathrm{Cr}$ & $\mathrm{Cu}$ & $\mathrm{Hg}$ & $\mathbf{N i}$ & $\mathrm{Pb}$ & Zn \\
\hline & & & $\begin{array}{c}\mathrm{N} \\
\text { (Percentage) }\end{array}$ & $\begin{array}{c}\mathrm{N} \\
\text { (Percentage) }\end{array}$ & $\begin{array}{c}\mathrm{N} \\
\text { (Percentage) }\end{array}$ & $\begin{array}{c}\mathrm{N} \\
\text { (Percentage) }\end{array}$ & $\begin{array}{c}\mathrm{N} \\
\text { (Percentage) }\end{array}$ & $\begin{array}{c}\mathrm{N} \\
\text { (Percentage) }\end{array}$ & $\begin{array}{c}\mathrm{N} \\
\text { (Percentage) }\end{array}$ & $\begin{array}{c}\mathrm{N} \\
\text { (Percentage) }\end{array}$ \\
\hline Children & $\begin{array}{l}\mathrm{HQ}_{\text {ingestion }} \\
\mathrm{HQ}_{\text {inhalation }} \\
\mathrm{HQ}_{\text {dermal }} \\
\mathrm{HI} \\
\mathrm{CHI}\end{array}$ & $\begin{array}{l}>1 \\
<1 \\
>1 \\
<1 \\
>1 \\
<1 \\
>1 \\
<1 \\
>1 \\
<1\end{array}$ & $\begin{array}{c}305(19.38 \%) \\
1269(80.62 \%) \\
0(0 \%) \\
1574(100 \%) \\
0(0 \%) \\
1574(100 \%) \\
308(19.57 \%) \\
1266(80.43 \%)\end{array}$ & $\begin{array}{c}0(0 \%) \\
1574(100 \%) \\
0(0 \%) \\
1574(100 \%) \\
0(0 \%) \\
1574(100 \%) \\
0(0 \%) \\
1574(100 \%)\end{array}$ & $\begin{array}{c}0(0 \%) \\
1574(100 \%) \\
0(0 \%) \\
1574(100 \%) \\
0(0 \%) \\
1574(100 \%) \\
0(0 \%) \\
1574(100 \%)\end{array}$ & $\begin{array}{c}0(0 \%) \\
1574(100 \%) \\
0(0 \%) \\
1574(100 \%) \\
0(0 \%) \\
1574(100 \%) \\
0(0 \%) \\
1574(100 \%) \\
505(3 \\
1069 \\
\end{array}$ & $\begin{array}{c}0(0 \%) \\
1574(100 \%) \\
0(0 \%) \\
1574(100 \%) \\
0(0 \%) \\
1574(100 \%) \\
0(0 \%) \\
1574(100 \%) \\
8 \%) \\
92 \%)\end{array}$ & $\begin{array}{c}0(0 \%) \\
1574(100 \%) \\
0(0 \%) \\
1574(100 \%) \\
0(0 \%) \\
1574(100 \%) \\
0(0 \%) \\
1574(100 \%)\end{array}$ & $\begin{array}{c}8(0.51 \%) \\
1566(99.49 \%) \\
0(0 \%) \\
1574(100 \%) \\
0(0 \%) \\
1574(100 \%) \\
8(0.51 \%) \\
1566(99.49 \%)\end{array}$ & $\begin{array}{c}0(0 \%) \\
1574(100 \%) \\
0(0 \%) \\
1574(100 \%) \\
0(0 \%) \\
1574(100 \%) \\
0(0 \%) \\
1574(100 \%)\end{array}$ \\
\hline Adults & $\begin{array}{l}\mathrm{HQ}_{\text {ingestion }} \\
\mathrm{HQ}_{\text {inhalation }} \\
\mathrm{HQ}_{\text {dermal }} \\
\mathrm{HI} \\
\mathrm{CHI}\end{array}$ & $\begin{array}{l}>1 \\
<1 \\
>1 \\
<1 \\
>1 \\
<1 \\
>1 \\
<1 \\
>1 \\
<1\end{array}$ & $\begin{array}{c}2(0.13 \%) \\
1572(99.87 \%) \\
0(0 \%) \\
1574(100 \%) \\
0(0 \%) \\
1574(100 \%) \\
4(0.25 \%) \\
1570(99.75 \%)\end{array}$ & $\begin{array}{c}0(0 \%) \\
1574(100 \%) \\
0(0 \%) \\
1574(100 \%) \\
0(0 \%) \\
1574(100 \%) \\
0(0 \%) \\
1574(100 \%)\end{array}$ & $\begin{array}{c}0(0 \%) \\
1574(100 \%) \\
0(0 \%) \\
1574(100 \%) \\
0(0 \%) \\
1574(100 \%) \\
0(0 \%) \\
1574(100 \%)\end{array}$ & $\begin{array}{c}0(0 \%) \\
1574(100 \%) \\
0(0 \%) \\
1574(100 \%) \\
0(0 \%) \\
1574(100 \%) \\
0(0 \%) \\
1574(100 \%) \\
9(0 \\
1565(\end{array}$ & $\begin{array}{c}0(0 \%) \\
1574(100 \%) \\
0(0 \%) \\
1574(100 \%) \\
0(0 \%) \\
1574(100 \%) \\
0(0 \%) \\
1574(100 \%) \\
\%) \\
43 \%)\end{array}$ & $\begin{array}{c}0(0 \%) \\
1574(100 \%) \\
0(0 \%) \\
1574(100 \%) \\
0(0 \%) \\
1574(100 \%) \\
0(0 \%) \\
1574(100 \%)\end{array}$ & $\begin{array}{c}0(0 \%) \\
1574(100 \%) \\
0(0 \%) \\
1574(100 \%) \\
0(0 \%) \\
1574(100 \%) \\
0(0 \%) \\
1574(100 \%)\end{array}$ & $\begin{array}{c}0(0 \%) \\
1574(100 \%) \\
0(0 \%) \\
1574(100 \%) \\
0(0 \%) \\
1574(100 \%) \\
0(0 \%) \\
1574(100 \%)\end{array}$ \\
\hline
\end{tabular}
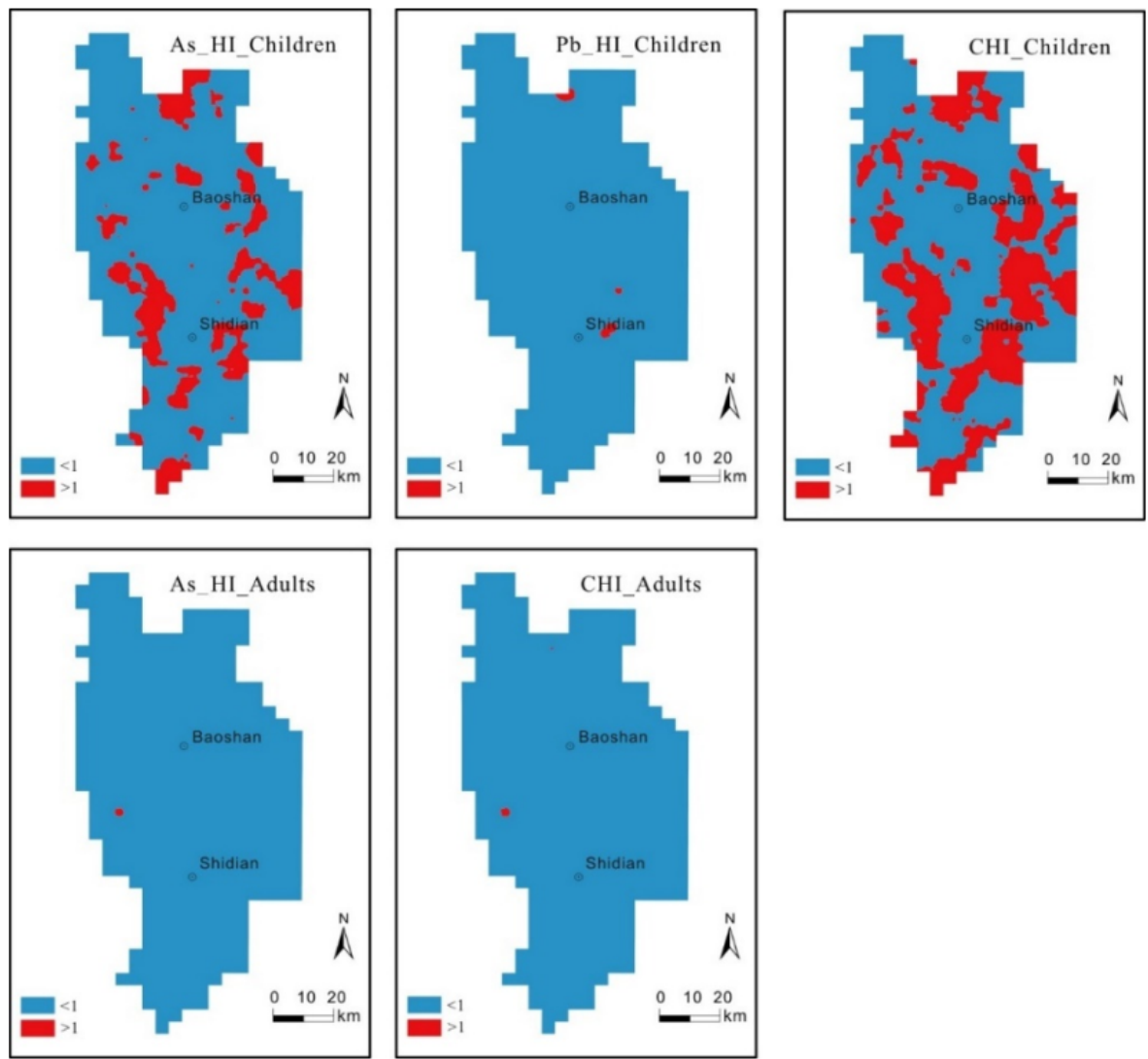

Figure 7. The distribution of counter maps of the non-carcinogenic risks (HI) and cumulative noncarcinogenic risk (CHI) determined by inverse distance-weighted (IDW) interpolation.

\subsubsection{Carcinogenic Risks to Humans}

Only the carcinogenic risks of $\mathrm{As}, \mathrm{Cd}, \mathrm{Cr}, \mathrm{Ni}$, and $\mathrm{Pb}$ to humans is examined in this chapter because only the carcinogenic slope factors of these researched PTEs have been previously determined in the literature. Table 8 shows the median values of carcinogenic risk assessment indictors, such as CDI and CR, for individually documented PTEs by individual routes, TCR for individual PTEs by total pathways, and CTCR for the cumulative values of these recorded PTEs by the total three pathways. 
Table 8. Median values of carcinogenic risk indictors to humans from soil PTEs.

\begin{tabular}{ccccccc}
\hline & & As & Cd & Cr & Ni & Pb \\
\hline & & Median & Median & Median & Median & Median \\
\hline \multirow{2}{*}{ CDI $_{\text {ingestion }}$} & Children & $1.35 \times 10^{-5}$ & $1.54 \times 10^{-7}$ & $1.55 \times 10^{-5}$ & $4.20 \times 10^{-5}$ & $2.77 \times 10^{-5}$ \\
& Adults & $7.70 \times 10^{-6}$ & $8.79 \times 10^{-8}$ & $8.84 \times 10^{-6}$ & $2.40 \times 10^{-5}$ & $1.58 \times 10^{-5}$ \\
$\mathrm{CDI}_{\text {inhalation }}$ & Children & $3.78 \times 10^{-16}$ & $4.31 \times 10^{-18}$ & $4.34 \times 10^{-16}$ & $1.18 \times 10^{-15}$ & $7.78 \times 10^{-16}$ \\
& Adults & $1.13 \times 10^{-9}$ & $1.29 \times 10^{-11}$ & $1.30 \times 10^{-9}$ & $3.53 \times 10^{-9}$ & $2.33 \times 10^{-9}$ \\
$\mathrm{CDI}_{\text {dermal }}$ & Children & $2.16 \times 10^{-8}$ & $2.46 \times 10^{-10}$ & $2.47 \times 10^{-8}$ & $6.72 \times 10^{-8}$ & $4.44 \times 10^{-8}$ \\
& Adults & $2.35 \times 10^{-7}$ & $2.68 \times 10^{-9}$ & $2.70 \times 10^{-7}$ & $7.32 \times 10^{-7}$ & $4.83 \times 10^{-7}$ \\
$\mathrm{CR}_{\text {ingestion }}$ & Children & $2.02 \times 10^{-5}$ & - & $7.73 \times 10^{-6}$ & - \\
& Adults & $1.15 \times 10^{-5}$ & - & $4.42 \times 10^{-6}$ & - \\
$\mathrm{CR}_{\text {inhalation }}$ & Children & $5.67 \times 10^{-15}$ & $2.72 \times 10^{-17}$ & $1.82 \times 10^{-14}$ & $9.89 \times 10^{-16}$ & $3.27 \times 10^{-16}$ \\
& Adults & $1.70 \times 10^{-8}$ & $8.14 \times 10^{-11}$ & $5.46 \times 10^{-8}$ & $2.96 \times 10^{-9}$ & $9.79 \times 10^{-10}$ \\
$\mathrm{CR}_{\text {dermal }}$ & Children & $7.89 \times 10^{-8}$ & - & - & - \\
& Adults & $8.59 \times 10^{-7}$ & - & - & - \\
TCR & Children & $2.03 \times 10^{-5}$ & $2.72 \times 10^{-17}$ & $7.73 \times 10^{-6}$ & $9.89 \times 10^{-16}$ & $3.27 \times 10^{-16}$ \\
& Adults & $1.24 \times 10^{-5}$ & $8.14 \times 10^{-11}$ & $4.47 \times 10^{-6}$ & $2.96 \times 10^{-9}$ & $9.79 \times 10^{-10}$ \\
CTCR & Children & & & $2.90 \times 10^{-5}$ & $1.74 \times 10^{-5}$ & \\
& Adults & & & & \\
\hline
\end{tabular}

Note: "-" not available.

Similar to non-carcinogenic risk, the median values of the carcinogenic CDI for all of the studied PTEs by direct oral ingestion was much higher than that by dermal contact and respiratory inhalation. The median values of the daily carcinogenic exposure of the three different pathways were ranked as follows: $\mathrm{CDI}_{\text {ingestion }}>\mathrm{CDI}_{\text {dermal }}>\mathrm{CDI}_{\text {inhalation }}$. Only the carcinogenic slope factors of As and $\mathrm{Cr}$ were provided by direct oral ingestion. Children have a substantially higher carcinogenic risk from As and $\mathrm{Cr}$ exposure than adults. Adults have higher carcinogenic hazards than children when it comes to respiratory inhalation and dermal contact. For children, the order of the median values of carcinogenic risk for the sum of the documented PTEs from the three overall pathways was as follows: As $>\mathrm{Cr}>\mathrm{Pb}>\mathrm{Ni}>\mathrm{Cd}$, and for adults, it was $\mathrm{As}>\mathrm{Cr}>\mathrm{Ni}>\mathrm{Pb}>\mathrm{Cd}$. The carcinogenic risk of children to all of the documented PTEs by the total pathways were higher than that of adults.

When considering all of the sample points of the study area, the carcinogenic risk by oral ingestion were considered to be acceptable for As (1532 sites, counting for $97.33 \%$ ) and $\mathrm{Ni}$ (1571 sites, counting for $99.81 \%$ ) for children and As (1561 sites, counting for $99.17 \%$ ) and $\mathrm{Ni}$ (1569 sites, counting for $99.68 \%$ ) for adults, respectively. Additionally, the carcinogenic risks of one site for As and three sites for $\mathrm{Cr}$ to children, and two sites for As and five sites for $\mathrm{Cr}$ to adults were considered to be negligible. For As, only 41 sites $(2.60 \%)$ and 11 sites $(0.70 \%)$ represented an unacceptable carcinogenic risk to children and adults via the oral ingestion pathway, respectively. For inhalation, all of the sites represented a negligible carcinogenic risk to both children and adults. With the exception of $2.67 \%$ (42 sites) and $0.76 \%$ (12 sites) of As, which pose a carcinogenic risk to children and adults, respectively, all of the other known PTEs pose a negligible or acceptable carcinogenic risk through all three pathways. In terms of the cumulative carcinogenic risk of all of the recorded PTEs via the three total pathways, $3.24 \%$ (51 sites) and $0.83 \%$ (13 sites) were considered to be unacceptable for children and adults, respectively. Arsenic contributed the most to the carcinogenic risk of all of the PTEs (Table 9).

Contour maps determined by IDW interpolation are presented to find the carcinogenic risk distributions of As and all of the PTEs via the three pathways (Figure 8). The distribution of places with unacceptable carcinogenic risk coincides with the distribution of $\mathrm{Hg}$ and $\mathrm{Cu}-\mathrm{Pb}-\mathrm{Zn}$ deposits, just as it does with non-carcinogenic risk. In addition, As had the highest slope factor of all of the examined PTEs, meaning that it poses the highest carcinogenic risk to humans. Although the overall carcinogenic risk in the study area is acceptable, residents living near the mine should be aware of the potential carcinogenic 
risk. The PTEs in the soil around mining areas demonstrate considerable non-carcinogenic and carcinogenic risks for local inhabitants, and this has been verified by a previous study by analysis of a large number of soil data around the mining area [5].
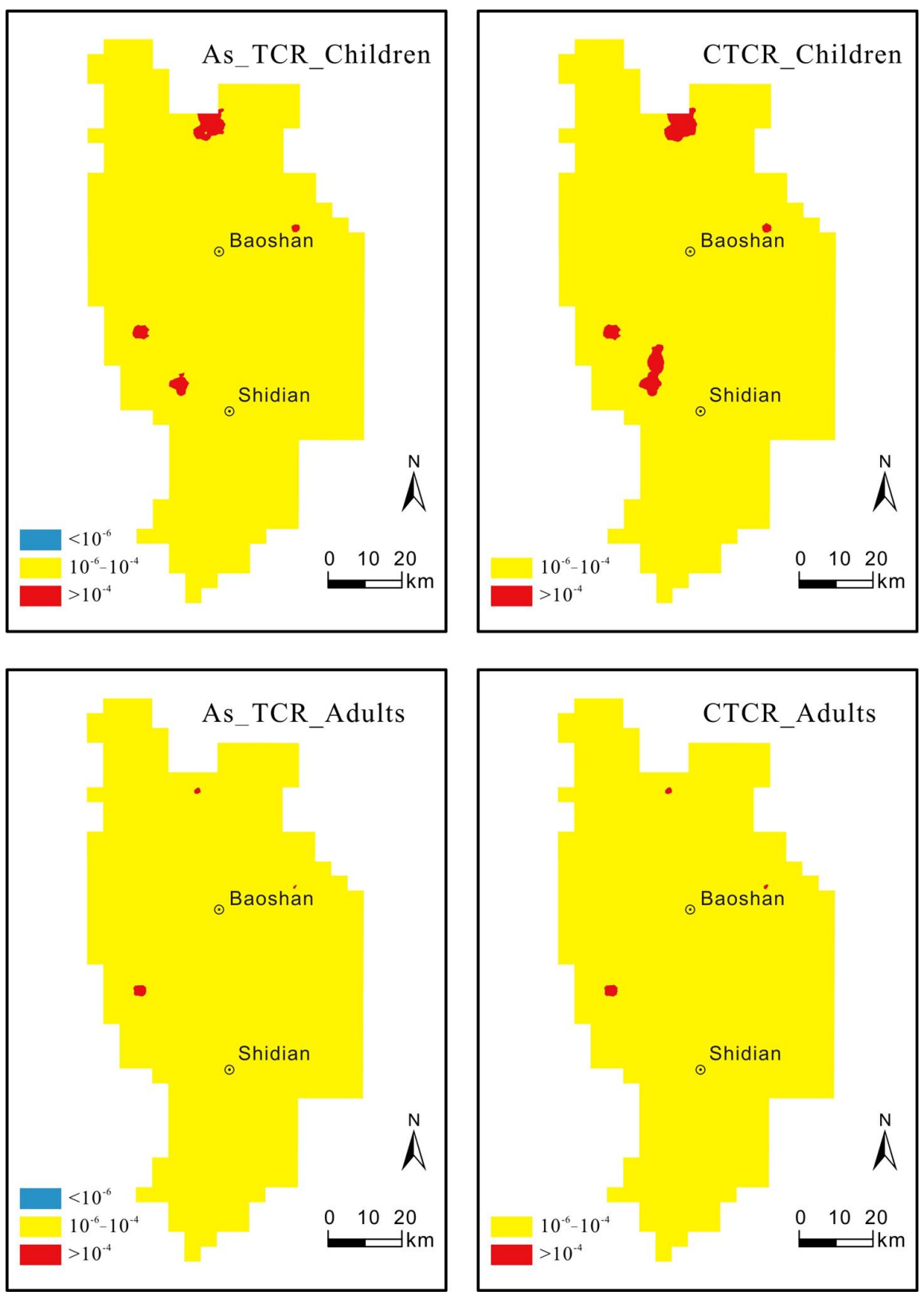

Figure 8. The distribution of counter maps of the carcinogenic risks (TCR) and cumulative carcinogenic risk (CTCR) determined by inverse distance-weighted (IDW) interpolation. 
Table 9. The sites number of sites (percentage) of carcinogenic risk levels to humans from soil PTEs.

\begin{tabular}{|c|c|c|c|c|c|c|c|c|c|c|}
\hline & & & As & $\mathrm{Cd}$ & $\mathrm{Cr}$ & $\mathrm{Cu}$ & $\mathrm{Hg}$ & $\mathrm{Ni}$ & $\mathrm{Pb}$ & Zn \\
\hline & & & $\begin{array}{c}\mathrm{N} \\
\text { (Percentage) }\end{array}$ & $\begin{array}{c}\mathrm{N} \\
\text { (Percentage) }\end{array}$ & $\begin{array}{c}\mathrm{N} \\
\text { (Percentage) }\end{array}$ & $\begin{array}{c}\mathrm{N} \\
\text { (Percentage) }\end{array}$ & $\begin{array}{c}\mathrm{N} \\
\text { (Percentage) }\end{array}$ & $\begin{array}{c}\mathrm{N} \\
\text { (Percentage) }\end{array}$ & $\begin{array}{c}\mathrm{N} \\
\text { (Percentage) }\end{array}$ & $\begin{array}{c}\mathrm{N} \\
\text { (Percentage) }\end{array}$ \\
\hline \multirow{9}{*}{ Children } & \multirow{3}{*}{$\mathrm{CR}_{\text {ingestion }}$} & $<1 \times 10^{-6}$ & $1(0.06 \%)$ & - & $3(0.19 \%)$ & - & - & - & - & - \\
\hline & & $1 \times 10^{-6} \sim 1 \times 10^{-4}$ & $\begin{array}{c}1532 \\
(97.33 \%)\end{array}$ & - & $1571(99.81 \%)$ & - & - & - & - & - \\
\hline & & $>1 \times 10^{-4}$ & $41(2.60 \%)$ & - & $0(0 \%)$ & - & - & - & - & - \\
\hline & \multirow{3}{*}{$\mathrm{CR}_{\text {inhalation }}$} & $<1 \times 10^{-6}$ & $1574(100 \%)$ & $1574(100 \%)$ & $1574(100 \%)$ & - & - & $1574(100 \%)$ & $1574(100 \%)$ & - \\
\hline & & $1 \times 10^{-6} \sim 1 \times 10^{-4}$ & $0(0 \%)$ & $0(0 \%)$ & $0(0 \%)$ & - & - & $0(0 \%)$ & $0(0 \%)$ & - \\
\hline & & $>1 \times 10^{-4}$ & $0(0 \%)$ & $0(0 \%)$ & $0(0 \%)$ & - & - & $0(0 \%)$ & $0(0 \%)$ & - \\
\hline & \multirow{3}{*}{$\mathrm{CR}_{\text {dermal }}$} & $<1 \times 10^{-6}$ & $\begin{array}{c}1571 \\
(99.81 \%)\end{array}$ & - & - & - & - & - & - & - \\
\hline & & $1 \times 10^{-6} \sim 1 \times 10^{-4}$ & $3(0.19 \%)$ & - & - & - & - & - & - & - \\
\hline & & $>1 \times 10^{-4}$ & $0(0 \%)$ & - & - & - & - & - & - & - \\
\hline \multirow{20}{*}{ Adults } & \multirow{3}{*}{ TCR } & $<1 \times 10^{-6}$ & $1(0.06 \%)$ & $1574(100 \%)$ & $3(0.19 \%)$ & - & - & $1574(100 \%)$ & $1574(100 \%)$ & - \\
\hline & & $1 \times 10^{-6} \sim 1 \times 10^{-4}$ & $\begin{array}{c}1531 \\
(9726 \%)\end{array}$ & $0(0 \%)$ & 1571 & - & - & $0(0 \%)$ & $0(0 \%)$ & - \\
\hline & & $>1 \times 10^{-4}$ & $42(2.67 \%)$ & $0(0 \%)$ & $0(0 \%)$ & - & - & $0(0 \%)$ & $0(0 \%)$ & - \\
\hline & \multirow[b]{2}{*}{ CTCR } & $<1 \times 10^{-6}$ & \multicolumn{8}{|c|}{$0(0 \%)$} \\
\hline & & $\begin{array}{c}1 \times 10^{-6} \sim 1 \times 10^{-4} \\
>1 \times 10^{-4}\end{array}$ & & & & $\begin{array}{r}1523(9 \\
51(3\end{array}$ & $\begin{array}{l}.76 \%) \\
4 \%)\end{array}$ & & & \\
\hline & \multirow{3}{*}{$\mathrm{CR}_{\text {ingestion }}$} & $<1 \times 10^{-6}$ & $2(0.13 \%)$ & - & $5(0.32 \%)$ & - & - & - & - & - \\
\hline & & $1 \times 10^{-6} \sim 1 \times 10^{-4}$ & $\begin{array}{c}1561 \\
(99.17 \%)\end{array}$ & - & $\begin{array}{c}1569 \\
(99.68 \%)\end{array}$ & - & - & - & - & - \\
\hline & & $>1 \times 10^{-4}$ & $11(0.70 \%)$ & - & $0(0 \%)$ & - & - & - & - & - \\
\hline & \multirow{3}{*}{$\mathrm{CR}_{\text {inhalation }}$} & $<1 \times 10^{-6}$ & $1574(100 \%)$ & $1574(100 \%)$ & $1574(100 \%)$ & - & - & $1574(100 \%)$ & $1574(100 \%)$ & - \\
\hline & & $1 \times 10^{-6} \sim 1 \times 10^{-4}$ & $0(0 \%)$ & $0(0 \%)$ & $0(0 \%)$ & - & - & $0(0 \%)$ & $0(0 \%)$ & - \\
\hline & & $>1 \times 10^{-4}$ & $0(0 \%)$ & $0(0 \%)$ & $0(0 \%)$ & - & - & $0(0 \%)$ & $0(0 \%)$ & - \\
\hline & \multirow{3}{*}{$\mathrm{CR}_{\text {dermal }}$} & $<1 \times 10^{-6}$ & $927(58.89 \%)$ & - & - & - & - & - & - & - \\
\hline & & $1 \times 10^{-6} \sim 1 \times 10^{-4}$ & $647(41.11 \%)$ & - & - & - & - & - & - & - \\
\hline & & $>1 \times 10^{-4}$ & $0(0 \%)$ & - & - & - & - & - & - & - \\
\hline & \multirow[b]{2}{*}{ TCR } & $<1 \times 10^{-6}$ & $2(0.13 \%)$ & $0(0 \%)$ & $5(0.32 \%)$ & - & - & $1574(100 \%)$ & $1574(100 \%)$ & - \\
\hline & & $1 \times 10^{-6} \sim 1 \times 10^{-4}$ & $\begin{array}{c}1560 \\
(99.11 \%)\end{array}$ & $1574(100 \%)$ & $\begin{array}{c}1569 \\
(99.68 \%)\end{array}$ & - & - & $0(0 \%)$ & $0(0 \%)$ & - \\
\hline & \multirow{4}{*}{ CTCR } & $>1 \times 10^{-4}$ & $12(0.76 \%)$ & $0(0 \%)$ & $0(0 \%)$ & - & - & $0(0 \%)$ & $0(0 \%)$ & - \\
\hline & & $<1 \times 10^{-6}$ & \multirow{3}{*}{\multicolumn{8}{|c|}{$\begin{array}{c}0(0 \%) \\
1561(99.17 \%) \\
13(0.83 \%)\end{array}$}} \\
\hline & & $1 \times 10^{-6} \sim 1 \times 10^{-4}$ & & & & & & & & \\
\hline & & $>1 \times 10^{-4}$ & & & & & & & & \\
\hline
\end{tabular}

\section{Conclusions}

The following conclusions can be drawn from the above research:

(1) The PTE values determined from partial surface soil samples from sites in the study area exceeded the RSV and RIV of soil environmental quality-the risk control standard for soil contamination of agricultural land of China, showing ecological risks;

(2) $\mathrm{Cd}$ and $\mathrm{Hg}$ posed higher ecological risks than the other PTEs (As, $\mathrm{Cr}, \mathrm{Pb}, \mathrm{Cu}, \mathrm{Ni}$, and $\mathrm{Zn}$ ) highlighted by their high toxic response factor;

(3) Arsenic is the main PTE that posed a non-carcinogenic risk, and the only PTE that poses a carcinogenic risk to humans. Children are more vulnerable to health risks than adults because of their behavioral and physiological traits;

(4) Geological genesis was responsible for the high concentrations, ecological risk, and health risk distribution patterns of the examined PTEs. The ecological and health risks of the PTEs in the surface soil that had developed from basalt and carbonatite rocks, particularly near mineral resources, were discovered in the study area. Future administration and research are needed, especially in mining areas.

Author Contributions: L.Z.: Conceptualization, Writing-Original Draft Preparation. Z.Y.: Software. M.P.: Project Administration, Supervision. X.C.: Formal Analysis. All authors have read and agreed to the published version of the manuscript.

Funding: This research was funded by China Geological Survey [DD20160313, DD20190522, and DD20190518] and Institute of Geophysical and Geochemical Exploration, Chinese Academy of Geological Sciences grant number [AS2019J02 and JY202105].

Institutional Review Board Statement: Not applicable.

Informed Consent Statement: Not applicable. 
Data Availability Statement: The data presented in this study are available on request from the corresponding author. The data are not publicly available due to the data are unified management by the project administrator.

\begin{abstract}
Acknowledgments: We would like to appreciate to Hangxin Cheng, Qiaolin Wang, Yuntao Song, Wei Han, Chengwen Wang, Fei Liu, Yalong Zhou, Zhibin Yang and all of the other participants from pre-Division of Geochemical Survey Methodology, Institute of Geophysical and Geochemical Exploration, Chinese Academy of Geological Sciences (IGGE, CAGS) for their project support and field work. The authors also would like to express our sincere thanks to the editors and reviewers for their critical and constructive comments and suggestions.
\end{abstract}

Conflicts of Interest: The authors declare that they have no known competing financial interests or personal relationships that could have appeared to influence the work reported in this work.

\title{
References
}

1. Cicchella, D.; De Vivo, B.; Lima, A.; Albanese, S.; McGill, R.A.R.; Parrish, R.R. Heavy metal pollution and Pb isotopes in urban soils of Napoli, Italy. Geochem. Explor. Environ. Anal. 2008, 8, 103-112. [CrossRef]

2. Kelepertzis, E.; Galanos, E.; Mitsis, I. Origin, mineral speciation and geochemical baseline mapping of $\mathrm{Ni}$ and $\mathrm{Cr}$ in agricultural topsoils of Thiva Valley (central Greece). J. Geochem. Explor. 2013, 125, 56-68. [CrossRef]

3. Li, X.; Cheng, H.; Zhao, C.; Xu, X. Mercury contamination in the topsoil and subsoil of urban areas of Beijing, China. Bull. Environ. Contam. Toxicol. 2010, 85, 224-228. [CrossRef] [PubMed]

4. Li, M.; Xi, X.; Xiao, G.; Cheng, H.; Yang, Z.; Zhou, G.; Ye, J.; Li, Z. National multipurpose regional geochemical survey in China. J. Geochem. Explor. 2014, 139, 21-30. [CrossRef]

5. Li, Z.; Ma, Z.; van der Kuijp, T.J.; Yuan, Z.; Huang, L. A review of soil heavy metal pollution from mines in China: Pollution and health risk assessment. Sci. Total Environ. 2014, 468, 843-853. [CrossRef]

6. Luo, X.S.; Yu, S.; Zhu, Y.G.; Li, X.D. Trace metal contamination in urban soils of China. Sci. Total Environ. 2012, 421-422, 17-30. [CrossRef]

7. Zhang, H.; Luo, Y.; Makino, T.; Wu, L.; Nanzyo, M. The heavy metal partition in size-fractions of the fine particles in agricultural soils contaminated by waste water and smelter dust. J. Hazard. Mater. 2013, 248, 303-312. [CrossRef]

8. Dong, J.; Yang, Q.W.; Sun, L.N.; Zeng, Q.; Liu, S.J.; Pan, J.; Liu, X.L. Assessing the concentration and potential dietary risk of heavy metals in vegetables at a $\mathrm{Pb} / \mathrm{Zn}$ mine site, China. Environ. Earth Sci. 2011, 64, 1317-1321. [CrossRef]

9. De Miguel, E.; De Grado, M.J.; Llamas, J.F.; Martın-Dorado, A.; Mazadiego, L.F. The overlooked contribution of compost application to the trace element load in the urban soil of Madrid (Spain). Sci. Total Environ. 1998, 215, 113-122. [CrossRef]

10. Li, H.; Qian, X.; Hu, W.; Wang, Y.; Gao, H. Chemical speciation and human health risk of trace metals in urban street dusts from a metropolitan city, Nanjing, SE China. Sci. Total Environ. 2013, 456, 212-221. [CrossRef]

11. Nabulo, G.; Young, S.D.; Black, C.R. Assessing risk to human health from tropical leafy vegetables grown on contaminated urban soils. Sci. Total Environ. 2010, 408, 5338-5351. [CrossRef]

12. Wu, S.; Peng, S.; Zhang, X.; Wu, D.; Luo, W.; Zhang, T.; Zhou, S.; Yang, G.; Wan, H.; Wu, L. Levels and health risk assessments of heavy metals in urban soils in Dongguan, China. J. Geochem. Explor. 2015, 148, 71-78. [CrossRef]

13. Liu, X.; Song, Q.; Tang, Y.; Li, W.; Xu, J.; Wu, J.; Wang, F.; Philip, C.B. Human health risk assessment of heavy metals in soil-vegetable system: A multi-medium analysis. Sci. Total Environ. 2013, 463, 530-540. [CrossRef]

14. IARC (International Agency for Research on Cancer). IARC Monographs on the Evaluation of Carcinogenic Risks to Humans; Inorganic and Organic Lead Compounds; World Health Organization; International Agency for Research on Cancer: Lyon, France, 2006; Volume 87.

15. IARC (International Agency for Research on Cancer). Arsenic, Metals, Fibres, and Dusts. A Review of Human Carcinogens; World Health Organization. International Agency for Research on Cancer: Lyon, France, 2012; Volume 100C.

16. Rodriguez-Barranco, M.; Lacasana, M.; Aguilar-Garduno, C.; Alguacil, J.; Gil, F.; Gonzalez-Alzaga, B.; Rojas-Garcia, A. Association of arsenic, cadmium and manganese exposure with neurodevelopment and behavioural disorders in children: A systematic review and meta-analysis. Sci. Total Environ. 2013, 454, 562-577. [CrossRef]

17. Tyler, C.R.; Allan, A.M. The effects of arsenic exposure on neurological and cognitive dysfunction in human and rodent studies: A review. Curr. Environ. Health Rep. 2014, 1, 132-147. [CrossRef]

18. US EPA (U.S. Environmental Protection Agency). A Decade of Children's Environmental Health Research (O. o. R. a. Development, Trans.); National Center for Environmental Research: Simpang Ampat, Malaysia, 2007.

19. WHO (World Health Organization). Cadmium; Environmental Health Criteria; WHO: Geneva, Switzerland, $1992 ;$ Volume 134.

20. Karim, Z.; Qureshi, B.A. Health risk assessment of heavy metals in urban soil of Karachi Pakistan. Hum. Ecol. Risk Assess. Int. J. 2014, 20, 658-667. [CrossRef]

21. Appleton, J.D.; Cave, M.R.; Wragg, J. Modelling lead bioaccessibility in urban topsoils based on data from Glasgow, London, Northampton and Swansea, UK. Environ. Pollut. 2012, 171, 265-272. [CrossRef]

22. ATSDR (Agency for Toxic Substances and Disease Registry). Toxicological Profile for Mercury; Department Of Health and Human Services, Public Health Service, Agency for Toxic Substances and Disease Registry: Atlanta, GA, USA, 1999. 
23. Marsh, D.O.; Clarkson, T.W.; Cox, C.; Myers, G.J.; Amin-Zaki, L.; Al-Tikriti, S. Fetal methylmercury poisoning. Relationship between concentration in single strands of maternal hair and health effects. Arch Neurol. 1987, 44, 1017-1022. [CrossRef]

24. NRC (National Research Council). Toxicologic Effects of Methylmercury; National Academy Press: Washington, DC, USA, 2000.

25. US EPA (U.S. Environmental Protection Agency). Mercury Study Report to Congress; Office of Air Quality Planning and Standards and Office of Research and Development, U.S. Environmental Protection Agency: Washington, DC, USA, 1997.

26. Zheng, N.; Wang, Q.C.; Zheng, D.M. Health risk of $\mathrm{Hg}, \mathrm{Pb}, \mathrm{Cd}, \mathrm{Zn}$, and $\mathrm{Cu}$ to the inhabitants around Huludao Zinc Plant in China via consumption of vegetables. Sci. Total Environ. 2007, 383, 81-89. [CrossRef]

27. Chowdhury, S.; Saha, P.D. Biosorption kinetics, thermodynamics and isosteric heat of sorption of $\mathrm{Cu}(\mathrm{II})$ onto Tamarindus indica seed powder. Colloids Surf. B Biointerfaces 2011, 88, 697-705. [CrossRef]

28. de Moraes, N.V.; Carey, M.; Neville, C.E.; Cruise, S.; McGuinness, B.; Kee, F.; Young, I.S.; Woodside, J.V.; Meharg Andrew, A. Water dilutes and alcohol concentrates urinary arsenic species when food is the dominant source of exposure. Expo Health 2020, 12, 699-710. [CrossRef]

29. Plum, L.M.; Rink, L.; Haase, H. The essential toxin: Impact of zinc on human health. Int. J. Environ. Res. Public Health 2010, 7, 1342-1365. [CrossRef]

30. US EPA (U.S. Environmental Protection Agency). Supplementary Guidance for Conducting Health Risk Assessment of Chemical Mixtures; Risk Assessment Forum Technical Panel: Washington, DC, USA, 2000.

31. Genchi, G.; Carocci, A.; Lauria, G.; Sinicropi, M.S.; Catalano, A. Nickel: Human Health and Environmental Toxicology. Int. J. Environ. Res. Public Health 2020, 17, 679. [CrossRef]

32. Dobrovolski, G.V.; Nikitin, E.D. Soils Functions in Biosphere and Ecosystems. In The Nature and Properties of Soils; Nauka Weil, R.R., Brady, N.C., Eds.; Pearson Education: London, UK, 2017.

33. Antibachi, D.; Kelepertzis, E.; Kelepertsis, A. Heavy metals in agricultural soils of the Mouriki-Thiva Area (Central Greece) and environmental impact implications. Soil Sediment Contam. Int. J. 2012, 21, 434-450. [CrossRef]

34. Becquer, T.; Quantin, C.; Rotte-Capet, S.; Ghanbaja, J.; Mustin, C.; Herbillon, A.J. Sources of trace metals in ferralsols in New Caledonia. Eur. J. Soil Sci. 2006, 57, 200-213. [CrossRef]

35. Bompoti, N.; Chrysochoou, M.; Dermatas, D. Geochemical characterization of Greek ophiolitic environments using statistical analysis. Environ. Processes 2015, 2, 5-21. [CrossRef]

36. Bonifacio, E.; Falsone, G.; Piazza, S. Linking Ni and Cr concentrations to soil mineralogy: Does it help to assess metal contamination when the natural background is high? J. Soils Sediments 2010, 10, 1475-1486. [CrossRef]

37. Tashakor, M.; Wan Zuhairi, Y.; Mohamad, H.; Ghani, A. Geochemical characteristics of serpentinite soils from Malaysia. Malays. J. Soil Sci. 2014, 18, 35-49.

38. Addo, M.A.; Darko, E.O.; Gordon, C.; Nyarko, B.J.B.; Gbadago, J.K.; Nyarko, E.; Affum, H.A.; Botwe, B.O. Evaluation of heavy metals contamination of soil and vegetation in the vicinity of a cement factory in the Volta Region, Ghana. Int. J. Sci. Technol. 2012, $2,40-50$.

39. Chiu, Y.P.; Li, D.W.; Shiau, Y.C. Study on heavy metal characteristics of soil in phosphorus tail. J. Residuals Sci. Technol. 2016, 13, 1-7. [CrossRef]

40. Hamzeh, M.A.; Aftabi, A.; Mirzaee, M. Assessing geochemical influence of traffic and other vehicle-related activities on heavy metal contamination in urban soils of Kerman city, using a GIS-based approach. Environ. Geochem. Health 2011, 33, 577-594. [CrossRef] [PubMed]

41. McGrath, D.; Tunney, H. Accumulation of cadmium, fluorine, magnesium, and zinc in soil after application of phosphate fertilizer for 31 years in a grazing trial. J. Plant Nutr. Soil Sci. 2010, 173, 548-553. [CrossRef]

42. Naghipour, D.; Gharibi, H.; Taghavi, K.; Jaafari, J. Influence of EDTA and NTA on heavy metal extraction from sandy-loam contaminated soils. J. Environ. Chem. Eng. 2016, 4, 3512-3518. [CrossRef]

43. Yousefi, M.; Saleh, H.N.; Mohammadi, A.A.; Mahvi, A.H.; Ghadrpoori, M.; Suleimanid, H. Data on water quality index for the groundwater in rural area Neyshabur County, Razavi province, Iran. Data Brief 2017, 15, 901-907. [CrossRef]

44. Niu, L.; Yang, F.; Xu, C.; Yang, H.; Liu, W. Status of metal accumulation in farmland soils across China: From distribution to risk assessment. Environ. Pollut. 2013, 176, 55-62. [CrossRef]

45. Huang, Y.; Li, T.; Wu, C.; He, Z.; Japenga, J.; Deng, M.; Yang, X. An integrated approach to assess heavy metal source apportionment in peri-urban agricultural soils. J. Hazard. Mater. 2015, 299, 540-549. [CrossRef]

46. Liu, L.; Liu, Q.; Ma, J.; Wu, H.; Qu, Y.; Gong, Y.; Yang, S.; An, Y.; Zhou, Y. Heavy metal(loid)s in the topsoil of urban parks in Beijing, China: Concentrations, potential sources, and risk assessment. Environ. Pollut. 2020, 260, 114083. [CrossRef]

47. Marinho Reis, A.P.; Shepherd, T.; Nowell, G.; Cachada, A.; Duarte, A.C.; Cave, M.; Wragg, J.; Patinha, C.; Dias, A.; Rocha, F.; et al. Source and pathway analysis of lead and polycyclic aromatic hydrocarbons in Lisbon urban soils. Sci. Total Environ. 2016, 573, 324-336. [CrossRef]

48. Silva, H.F.; Silva, N.F.; Oliveira, C.M.; Matos, M.J. Heavy Metals Contamination of Urban Soils-A Decade Study in the City of Lisbon, Portugal. Soil Syst. 2021, 5, 27. [CrossRef]

49. Poňavič, M.; Wittlingerová, Z.; Čoupek, P.; Jan, B. Soil geochemical mapping of the central part of Prague, Czech Republic. J. Geochem. Explor. 2018, 187, 118-130. [CrossRef]

50. Liu, S.Y.; Tian, S.H.; Li, K.X.; Wang, L.P.; Liang, T. Heavy metal bioaccessibility and health risks in the contaminated soil of an abandoned, small-scale lead and zinc mine. Environ. Sci. Pollut. Res. 2018, 25, 15044-15056. [CrossRef] 
51. Elmayel, I.; Esbrí, J.M.; García-Ordiales, E.; Elouaer, Z.; Garcia-Noguero, E.M.; Bouzid, J.; Campos, J.; Higueras, P. Biogeochemical assessment of the impact of mining activity in the area of Jebal Trozza mine, central Tunisia. Environ. Geochem. Health 2020, 42, 3529-3542. [CrossRef]

52. Wang, Y.; Wang, R.; Fan, L.; Chen, T.; Bai, Y.; Yu, Q.; Liu, Y. Assessment of multiple exposure to chemical elements and health risks among residents near Huodehong lead-zinc mining area in Yunnan, southwest China. Chemosphere 2017, 174, 613-627. [CrossRef]

53. Cabral-Pinto, M.; MInácio Neves, O.; Almeida, A.A.; Pinto, E.; Oliveiros, B. Human health risk assessment due to agricultural activities and crop consumption in the surroundings of an industrial area. Expo. Health 2020, 12, 629-640. [CrossRef]

54. Zhang, L.; McKinley, M.J.; Cooper, M.; Peng, M.; Wang, Q.; Song, Y.; Cheng, H. A regional soil and river sediment geochemical study in Baoshan area, Yunnan province, southwest China. J. Geochem. Explor. 2020, 217, 106557. [CrossRef]

55. Zhang, L.; Mckinley, J.; Cooper, M.; Han, W.; Liu, F.; Song, Y.T.; Peng Min Liu, X.J.; Yang, W.; Cheng, H.X. Transfer processes of potential toxic elements (PTE) between rock-soil systems and soil risk evaluation in the baoshan area, yunnan province, southwest china. Appl. Geochem. 2020, 121, 104712. [CrossRef]

56. Barsby, A.; McKinley, J.M.; Ofterdinger, U.; Young, M.; Cave, M.R.; Wragg, J. Bioaccessibility of trace elements in soils in Northern Ireland. Sci. Total Environ. 2012, 433, 398-417. [CrossRef]

57. Cabral-Pinto, M.M.S.; Silva, M.M.V.G.; Ferreira da Silva, E.A.; Dinis, P.A.; Rocha, F. Transfer processes of potentially toxic elements (PTE) from rocks to soils and the origin of PTE in soils: A case study on the island of Santiago (Cape Verde). J. Geochem. Explor. 2017, 183, 140-151. [CrossRef]

58. Cheng, X.M. Geochemical Behavior and Risk Analysis for Heavy Elements in Soil Profiles with Different Parent Material, Yunnan Province, China; China University of Geosciences: Beijing, China, 2016; (In Chinese with English abstract).

59. Cox, S.F.; Rollinson, G.; McKinley, J.M. Mineralogical characterisation to improve understanding of oral bioaccessibility of Cr and $\mathrm{Ni}$ in basaltic soils in Northern Ireland. J. Geochem. Explor. 2017, 183, 166-177. [CrossRef]

60. Goldhaber, M.B.; Morrison, J.M.; Holloway, J.M.; Wanty, R.B.; Helsel, D.R.; Smith, D.B. A regional soil and sediment geochemical study in northern California. Appl. Geochem. 2009, 24, 1482-1499. [CrossRef]

61. Tolosana-Delgado, R.; McKinley, J. Exploring the joint compositional variability of major components and trace elements in the Tellus soil geochemistry survey (Northern Ireland). Appl. Geochem. 2016, 75, 263-276. [CrossRef]

62. Wang, X.; Liu, X.; Han, Z.; Zhou, J.; Xu, S.; Zhang, Q.; Chen, H.; Bo, W.; Xia, X. Concentration and distribution of mercury in drainage catchment sediment and alluvial soil of China. J. Geochem. Explor. 2015, 154, 32-48. [CrossRef]

63. Zhang, X.P.; Wei, D.; Yang, X.M. The background concentrations of 13 soil trace elements and their relationships to parent materials and vegetation in Xizang (Tibet), China. J. Asian Earth Sci. 2002, 21, 167-174. [CrossRef]

64. Zhang, L.; Han, W.; Peng, M.; Liu, F.; Song, Y.T.; Liu, X.J.; Wang, Q.L.; Li, K.; Zhao, D.J.; Yang, W.; et al. Geochemical characteristics of rare earth elements (REEs) in soils developed on different parent materials, in the baoshan area, yunnan province, southwest China. Geochem. Explor. Environ. Anal. 2021, 21, geochem2019-082. [CrossRef]

65. Dong, M.; Dong, G.; Mo, X.; Santosh, M.; Zhu, D.; Yu, J.; Nie, F.; Hu, Z. Geochemistry, zircon U-Pb geochronology and Hf isotopes of granites in the Baoshan Block, Western Yunnan: Implications for Early Paleozoic evolution along the Gondwana margin. Lithos 2013, 179, 36-47. [CrossRef]

66. Li, D.; Chen, Y.; Hou, K.; Lu, Z.; Cui, D. Detrital zircon record of Paleozoic and Mesozoic meta-sedimentary strata in the eastern part of the Baoshan block: Implications of their provenance and the tectonic evolution of the southeastern margin of the Tibetan plateau. Lithos 2015, 227, 194-204. [CrossRef]

67. Wang, Y.; Zhang, A.; Fan, W.; Peng, T.; Zhang, F.; Zhang, Y.; Bi, X. Petrogenesis of late Triassic post-collisional basaltic rocks of the Lancangjiang tectonic zone, southwest China, and tectonic implications for the evolution of the eastern Paleotethys: Geochronological and geochemical constraints. Lithos 2010, 120, 529-546. [CrossRef]

68. Wang, Y.; Xing, X.; Cawood, P.A.; Lai, S.; Xia, X.; Fan, W.; Liu, H.; Zhang, F. Petrogenesis of early Paleozoic peraluminous granite in the Sibumasu Block of SW Yunnan and diachronous accretionary orogenesis along the northern margin of Gondwana. Lithos 2013, 182, 67-85. [CrossRef]

69. CGS (China Geological Survey). Specification for Multi-Purpose Regional Geochemical Survey (DD/T 0258-2014); China Geological Survey: Beijing, China, 2014. (In Chinese)

70. Barbieri, M. The importance of enrichment factor (EF) and geoaccumulation index (Igeo) to evaluate the soil contamination. $J$. Geol. Geophys. 2016, 5, 1000237. [CrossRef]

71. Müller, G. Index of geoaccumulation in sediments of the Rhine river. J. Geol. 1969, 2, 108-118.

72. Hakanson, L. An ecological risk index for aquatic pollution control. A sedimentological approach. Water Res. 1980, 14, 975-1001. [CrossRef]

73. Ahmad, N.; Pandey, P. Spatio-temporal distribution, ecological risk assessment, and multivariate analysis of heavy metals in bathinda district, punjab, india. Water Air Soil Pollut. 2020, 231, 1-32. [CrossRef]

74. Bineshpour, M.; Payandeh, K.; Nazarpour, A.; Sabzalipour, S. Status, source, human health risk assessment of potential toxic elements (PTEs), and $\mathrm{Pb}$ isotope characteristics in urban surface soil, case study: Arak city, Iran. Environ. Geochem. Health 2020, 43, 4939-4958. [CrossRef] [PubMed]

75. Li, X.; Wu, T.; Bao, H.; Liu, X.; Xu, C.; Zhao, Y.; Liu, D.; Yu, H. Potential toxic trace element (PTEs) contamination in baoji urban soil (NW china): Spatial distribution, mobility behavior, and health risk. Environ. Sci. Pollut. Res. 2017, 24, 19749-19766. [CrossRef] 
76. Balls, P.W.; Hull, S.; Miller, B.S.; Pirie, J.M.; Proctor, W. Trace metal in Scottish estuarine and coastal sediments. Mar. Pollut. Bull. 1997, 34, 42-50. [CrossRef]

77. Ryan, J.D.; Windom, H.L. A Geochemical and Statistical Approach for Assessing Metal Pollution in Coastal Sediments; Springer: Berlin/Heidelberg, Germany, 1988; pp. 47-58.

78. Sinex, S.A.; Wright, D.A. Distribution of trace metals in the sediments and biota of Chesapake Bay. Mar. Pollut. Bull. 1988, 19, 425-431. [CrossRef]

79. Cheng, H.X.; Li, K.; Li, M.; Yang, K.; Liu, F.; Cheng, X.M. Geochemical background and baseline value of chemical elements in urban soil in China. Earth Sci. Front. 2014, 21, 265-306, (In Chinese with English abstract).

80. US EPA (U.S. Environmental Protection Agency). Risk Assessment Guidance for Superfund. Human Health Evaluation Manual, (Part A); Office of Emergency and Remedial Response: Washington, DC, USA, 1989; Volume 1.

81. Kumar, A.; Cabral Pinto, M.; Kumar, A.; Kumar, M.; Dinis, P. Estimation of Risk to the Eco-Environment and Human Health of Using Heavy Metals in the Uttarakhand Himalaya, India. Appl. Sci. 2020, 10, 7078. [CrossRef]

82. US EPA (U.S. Environmental Protection Agency). Supplemental Guidance for Developing Soil Screening Levels for Superfund Sites; Office of Emergency and Remedial Response: Washington, DC, USA, 2002.

83. Tepanosyan, G.; Sahakyan, L.; Maghakyan, N.; Saghatelyan, A. Identification of spatial patterns, geochemical associations and assessment of origin-specific health risk of potentially toxic elements in soils of armavir region, armenia. Chemosphere 2020, 262, 128365. [CrossRef]

84. RAIS (the Risk Assessment Information System). Risk Exposure Models for Chemicals User's Guide. Risk Assess. Inf. Syst. URL, 1.1.20. 2020. Available online: https:/ / rais.ornl.gov/tools/rais_chemical_risk_guide.html (accessed on 1 January 2022).

85. Sun, X.; Zhang, L.; Lv, J. Spatial assessment models to evaluate human health risk associated to soil potentially toxic elements. Environ. Pollut. 2021, 268, 115699. [CrossRef]

86. Pavlović, D.; Pavlović, M.; Perović, V.; Mataruga, Z.; Čakmak, D.; Mitrović, M.; Pavlović, P. Chemical Fractionation, Environmental, and Human Health Risk Assessment of Potentially Toxic Elements in Soil of Industrialised Urban Areas in Serbia. Int. J. Environ. Res. Public Health 2021, 18, 9412. [CrossRef]

87. Wang, X.Q.; Zhou, J.; Xu, S.F.; Chi, Q.H.; Nie, L.S.; Zhang, B.M.; Yao, W.S.; Wang, W.; Liu, H.L.; Liu, D.S.; et al. China soil geochemical baselines networks: Data characteristics. Chin. Geol. 2016, 43, 1469-1480, (In Chinese with English abstract).

88. CNEMC (China National Environmental Monitoring Center). The Soil Background Value in China; China Environmental Science Press: Beijing, China, 1990. (In Chinese)

89. Reimann, C.; Caritat, P. Establishing geochemical background variation and threshold values for 59 elements in Australian surface soil. Sci. Total Environ. 2017, 578, 633-648. [CrossRef]

90. David, B.S.; William, F.C.; Laurel, G.W.; Federico, S.; James, E.K.; David, L.F. Geochemical and Mineralogical Data for Soils of the Conterminous United States; U.S. Geological Survey: Reston, Virginia, 2013.

91. Salminen, R.; Batista, M.J.; Bidovec, M.; Demetriades, A.; De Vivo, B.; De Vos, W.; Duris, M.; Gilucis, A.; Gregorauskiene, V.; Halamic, J.; et al. Geochemical Atlas of Europe. Part 1: Background Information, Methodology and Maps; Geological Survey of Finland: Espoo, Finland, 2005.

92. Wei, Y.; Li, G.; Wang, Y.; Zhang, Q.; Li, B.; Wang, S.; Cui, J.; Zhang, H.; Zhou, Q. Investigating factors influencing the PMF model: A case study of source apportionment of heavy metals in farmland soils near a lead-zinc ore. J. Agro-Environ. Sci. 2018, 37, 2549-2559, (In Chinese with English Abstract).

93. Ma, H.; Peng, M.; Liu, F.; Guo, F.; Tang, S.; Liu, X.; Zhou, Y.; Yang, K.; Li, K.; Yang, Z.; et al. Bioavailability, Translocation, and Accumulation Characteristic of Heavy Metals in a Soil-Crop System from a Typical Carbonate Rock Area in Guangxi, China. Environ. Sci. 2020, 41, 449-459, (In Chinese with English Abstract).

94. Ackerman, F. A procedure for correcting grain size effect in heavy metal analysis of estuaries and coastal sediments. Environ. Technol. Lett. 1980, 1, 518-527. [CrossRef]

95. MEEC (Ministry of Ecology and Environment of The People's Republic of China). Soil Environmental Quality-Risk Control for Soil Contamination of Agricultural Land (GB-15618-2018); Ministry of Ecology and Environment of the People's Republic of China: Beijing, China, 2018. (In Chinese)

96. Grousset, F.E.; Quetel, C.R.; Thomas, B.; Donard, O.F.X.; Lambert, C.E.; Quillard, F.; Monaco, A. Anthropogenic vs. lithogenic origins of trace elements (As, Cd, Pb, Rb, Sb, Sc, Sn, and Zn) in water column particles: Northwestern Mediterranean Sea. Mar. Chem. 1995, 48, 291-310. [CrossRef]

97. Williams, J.A.; Antoine, J. Evaluation of the elemental pollution status of Jamaican surface sediments using enrichment factor, geoaccumulation index, ecological risk and potential ecological risk index. Mar. Pollut. Bull. 2020, 157, 111288. [CrossRef]

98. Tenkate, T. Environmental Health Risk Assessment: Guidelines for Assessing Human Health Risks from Environmental Hazards; Department of Health and Aging and Health Council: Canberra, Australia, 2002. 